Article

\title{
Bromotryptamine and Bromotyramine Derivatives from the Tropical Southwestern Pacific Sponge Narrabeena nigra
}

\author{
Maria Miguel-Gordo ${ }^{1}{ }^{(D}$, Sandra Gegunde ${ }^{2}{ }^{(}$, Kevin Calabro ${ }^{1}$, Laurence K. Jennings ${ }^{1}{ }^{(\mathbb{C}}$, \\ Amparo Alfonso ${ }^{2}$ (D), Grégory Genta-Jouve ${ }^{3,4}$ (D) , Jean Vacelet ${ }^{5}$, Luis M. Botana ${ }^{2, *(D)}$ \\ and Olivier P. Thomas ${ }^{1, *(D)}$ \\ 1 Marine Biodiscovery, School of Chemistry and Ryan Institute, National University of Ireland \\ Galway (NUI Galway), University Road, H91 TK33 Galway, Ireland; \\ m.miguelgordo1@nuigalway.ie (M.M.-G.); kevin.calabro@nuigalway.ie (K.C.); \\ laurence.jennings@nuigalway.ie (L.K.J.) \\ 2 Departamento de Farmacología, Facultad de Veterinaria, Universidade de Santiago de Compostela, \\ 27002 Lugo, Spain; sandra.gegunde@rai.usc.es (S.G.); amparo.alfonso@usc.es (A.A.) \\ 3 Laboratoire de Chimie-Toxicologie Analytique et Cellulaire (C-TAC) UMR CNRS 8038 CiTCoM Université \\ Paris-Descartes, 4, avenue de l'Observatoire, 75006 Paris, France; gregory.genta-jouve@parisdescartes.fr \\ 4 Muséum National d'Histoire Naturelle, Unité Molécules de Communication et Adaptation des \\ Micro-organismes (UMR 7245), Sorbonne Universités, CNRS, 75005 Paris, France \\ 5 Aix Marseille Université, CNRS, IRD, IMBE UMR 7263, Avignon Université, Institut Méditerranéen de \\ Biodiversité et d'Ecologie marine et continentale, Station Marine d'Endoume, Chemin de la Batterie des \\ Lions, 13007 Marseille, France; jean.vacelet@imbe.fr \\ * Correspondence: luis.botana@usc.es (L.M.B.); olivier.thomas@nuigalway.ie (O.P.T.); \\ Tel.: +34-9828-22233 (L.M.B.); +353-9149-3563 (O.P.T.)
}

Received: 28 April 2019; Accepted: 28 May 2019; Published: 30 May 2019

\begin{abstract}
So far, the Futuna Islands located in the Central Indo-Pacific Ocean have not been inventoried for their diversity in marine sponges and associated chemical diversity. As part of the Tara Pacific expedition, the first chemical investigation of the sponge Narrabeena nigra collected around the Futuna Islands yielded 18 brominated alkaloids: seven new bromotryptamine derivatives 1-7 and one new bromotyramine derivative 8 together with 10 known metabolites of both families 9-18. Their structures were deduced from extensive analyses of nuclear magnetic resonance (NMR) and high-resolution mass spectrometry (HRMS) data. In silico metabolite anticipation using the online tool MetWork revealed the presence of a key and minor biosynthetic intermediates. These 18 compounds showed almost no cytotoxic effect up to $10 \mu \mathrm{M}$ on human neuroblastoma SH-SY5Y and microglia BV2 cells, and some of them exhibited an interesting neuroprotective activity by reducing oxidative damage.
\end{abstract}

Keywords: Futuna; Porifera; Narrabeena; coral reefs; aromatic alkaloids; Bromotryptamine; Bromotyramine; neuroprotective agents

\section{Introduction}

Bioprospection represents the first step of the marine biodiscovery process, followed by the description of bioactive molecules, which can find applications especially in human health and the pharmaceutical sector. The Indo-Pacific Ocean is considered a key geographical area for marine biodiscovery, not only because of its luxuriant marine biodiversity, but also because marine invertebrates of remote islands usually present a high rate of endemicity, then leading to a potential chemical novelty. Importantly, inventories of the marine biodiversity around isolated islands also contribute to a global 
understanding of our oceans using an integrative approach composed of taxonomy, chemistry, ecology, biology, biochemistry, and microbiology [1-3]. The Tara Pacific expedition (2016-2018) explored the Pacific Ocean with the main scientific objective to conduct a comprehensive description of the marine biodiversity present in endangered coral reefs, from genes to ecosystem. In this context, an inventory of marine sponges was achieved in some locations for the first time, with the second objective to describe their associated chemical diversity [4]. The islands of Wallis and Futuna are located in the biodiversity-rich Tropical Southwestern Pacific, and only little information has been given about the biodiversity of marine invertebrates in this territory, mostly around the island of Wallis $[5,6]$. To the best of our knowledge, no detailed inventory of littoral sponges has been reported so far from the Futuna Islands composed of the two islands: Futuna and Alofi [7-9].

Following preliminary chemical profiling of the fractions obtained from sponges collected in this area, the sponge Narrabeena nigra Kim and Sim, 2010, first described in Korea [10] was selected for a thorough chemical investigation due to the presence of a high diversity of brominated alkaloids. Even though no natural products have been reported for species of this genus, other species of the Thorectidae family such as Smenospongia sp. and Hyrtios sp. are known to produce metabolites of this family with cytotoxic [11-13], anti-inflammatory, antioxidant [14], and antidepressant activities [15]. We describe herein the isolation and structure elucidation of seven new bromotryptamine metabolites 1-7 and a new bromotyramine derivative 8 (Figure 1), along with 10 known brominated analogues: 5,6-dibromo- $N, N$-dimethyltryptamine (9) [16,17], 5,6-dibromo- $N$-methyltryptamine (10) [18], 5,6-dibromotryptamine (11) [18], 6-bromo- $N$-methyltryptamine (12) [19], 6-bromotryptamine (13) [20,21], 6-bromokynuramine (14) [22], 7-bromoquinolin-4(1H)-one (15) [22], 3,5-dibromo-4-methoxytyramine (16) [23], 3-bromo-4-methoxy- $N, N, N$-trimethyltyrosine (17) [24], and 3-bromo-4-methoxytyramine (18), isolated for the first time as a natural product but widely used as a reactant in synthesis [23]. The biological activity of these alkaloids was assessed on two cellular models associated with neuroinflammation [25].

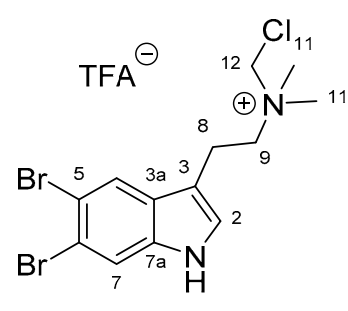

1

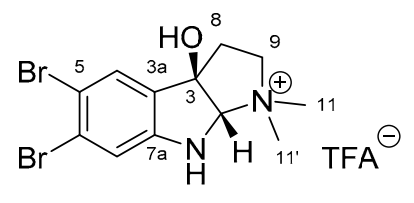

5

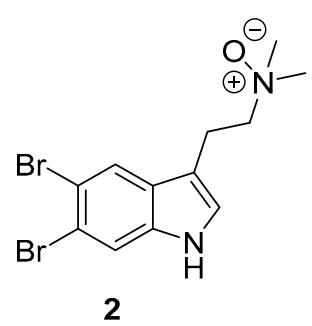

2

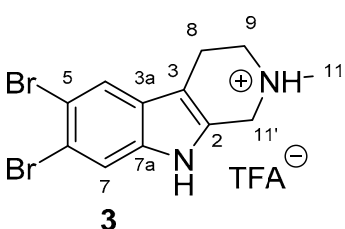

3<smiles>CNCCC1(O)C(=O)Nc2cc(Br)c(Br)cc21</smiles>

4<smiles>[R]c1c(N)c(C(=O)CC[NH-])cc(Br)c1Br</smiles>

$\mathrm{R}_{1}$

$6 \mathrm{H}$

$7 \mathrm{OCH}_{3}$

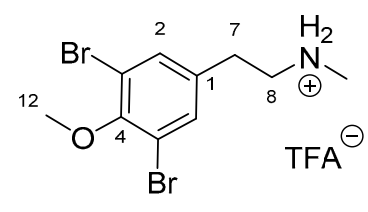

8

Figure 1. Chemical structures of seven new bromotryptamine and one new bromotyramine derivatives isolated from the sponge Narrabeena nigra.

\section{Results and Discussion}

\subsection{Isolation and Structure Elucidation}

The freeze-dried sponge sample $(66.8 \mathrm{~g})$ was extracted with $\mathrm{MeOH} / \mathrm{CH}_{2} \mathrm{Cl}_{2}$ (1:1) under sonication three times. The extract was then fractionated by reversed phase (RP)-C18 vacuum liquid chromatography (VLC) with solvents of decreasing polarity: $\mathrm{H}_{2} \mathrm{O}, \mathrm{H}_{2} \mathrm{O} / \mathrm{MeOH}(1: 1), \mathrm{MeOH}$, 
$\mathrm{MeOH} / \mathrm{CH}_{2} \mathrm{Cl}_{2}$ (1:1), and $\mathrm{CH}_{2} \mathrm{Cl}_{2}$. Compounds of the $\mathrm{H}_{2} \mathrm{O} / \mathrm{MeOH}, \mathrm{MeOH}$, and $\mathrm{MeOH} / \mathrm{CH}_{2} \mathrm{Cl}_{2}$ fractions were then purified by repeated preparative, semi-preparative, and analytical RP-HPLC, leading to the isolation of 18 pure metabolites, including the new tryptamine alkaloids 1-7 and the new tyramine derivative 8 . As the known 5,6-dibromo- $N, N$-dimethyltryptamine (9) and 3,5-dibromo-4-methoxytyramine (16) were found to be the major metabolites of the extract, the structures of the new metabolites were mainly deduced by comparison of their nuclear magnetic resonance (NMR) and high resolution mass spectrometry (HRMS) spectra with those of both $\mathbf{9}$ and $\mathbf{1 6}$.

Compound 1 was isolated as a yellow amorphous solid, and its HRMS spectrum revealed the molecular formula $\mathrm{C}_{13} \mathrm{H}_{16} \mathrm{Br}_{2} \mathrm{ClN}_{2}$ calculated from the ion at $\mathrm{m} / \mathrm{z} 392.9366[\mathrm{M}]^{+}$and an isotopic pattern characteristic of the presence of two bromine and one chlorine atoms. The ${ }^{1} \mathrm{H}$ NMR spectrum of 1 evidenced the presence of a 3, 5, 6-trisubstituted indole ring system with characteristic singlets at $\delta_{\mathrm{H}} 7.30(\mathrm{~s}, \mathrm{H}-2), 7.98(\mathrm{~s}, \mathrm{H}-4)$, and $7.74(\mathrm{~s}, \mathrm{H}-7)$ (Table 1). Two additional signals of the $\mathrm{AA}^{\prime} \mathrm{XX}^{\prime}$ system at $\delta_{\mathrm{H}} 3.27(\mathrm{H}-8)$ and the deshielded signal at $\delta_{\mathrm{H}} 3.73(\mathrm{H}-9)$ were reminiscent of a quaternary tryptammonium ion. The signal at $\delta_{\mathrm{H}} 3.33\left(\mathrm{~s}, \mathrm{H}_{3}-11\right.$ and $\left.\mathrm{H}_{3}-11^{\prime}\right)$ first revealed two equivalent methyls placed on the terminal amine. When comparing with known derivatives of this family, the NMR data of $\mathbf{1}$ were similar to those of the known 5,6-dibromo- $N, N$-dimethyltryptamine (9), with the presence of an additional deshielded signal of a methylene group at $\delta_{\mathrm{H}} 5.39\left(\mathrm{~s}, \mathrm{H}_{2}-12\right)$ and $\delta_{C} 68.2$ (C-12) (Tables 1 and 2) [17]. These unusual signals perfectly matched with the signals corresponding to the rare $\mathrm{N}$-(chloromethyl) substituent, as exemplified by NMR data of plant $N$-(chloromethyl)tryptamine derivatives [26]. The structure was confirmed first using the key H-12/C-9, C-11 and C-11' heteronuclear multiple bond correlation (HMBC) correlations and then the fragments at $m / z 344.9466$ and 301.8995 in the HRMS/MS spectrum of 1, indicative of the loss of a $\mathrm{N}$-chloromethyl and chloromethyldimethylamine moieties, respectively. Therefore, $\mathbf{1}$ was identified as the trifluoroacetate (TFA) salt of 5,6-dibromo- $N$-chloromethyl- $N, N$-dimethyltryptammonium. $\mathrm{N}$-chloromethyl derivatives have been commonly found as artefact products of the alkylation of tertiary amines by dichloromethane [27]. As we were unable to find a trace of $\mathbf{1}$ by ultra-high performance liquid chromatography (UHPLC)-HRMS/MS analysis of the ethanolic extract prepared from the same sponge specimen, we could conclude that $\mathbf{1}$ is produced during the extraction process.

Table 1. ${ }^{1} \mathrm{H}$ NMR data: $\delta_{\mathrm{H}}$ in ppm, mult. $(\mathrm{J}$ in $\mathrm{Hz})$, in $\mathrm{CD}_{3} \mathrm{OD}$ for $\mathbf{1 - 7}$ and 9.

\begin{tabular}{|c|c|c|c|c|c|c|c|c|}
\hline Position & $9^{a}$ & $1^{b}$ & $2^{b}$ & $3^{a}$ & $4^{b}$ & $5^{a}$ & $6^{a}$ & $7^{a}$ \\
\hline 2 & 7.26 & $7.30, \mathrm{~s}$ & $7.26, \mathrm{~s}$ & - & - & $5.18, \mathrm{~s}$ & - & - \\
\hline 4 & $7.93, \mathrm{~s}$ & $7.98, \mathrm{~s}$ & $7.99, \mathrm{~s}$ & $7.85, \mathrm{~s}$ & $7.73, \mathrm{~s}$ & $7.62, \mathrm{~s}$ & $7.98, \mathrm{~s}$ & $7.87, \mathrm{~s}$ \\
\hline 7 & $7.70, \mathrm{~s}$ & $7.74, \mathrm{~s}$ & $7.72, \mathrm{~s}$ & $7.72, \mathrm{~s}$ & $7.25, \mathrm{~s}$ & $7.14, \mathrm{~s}$ & $7.19, \mathrm{~s}$ & - \\
\hline $\begin{array}{l}8 \mathrm{a} \\
8 \mathrm{~b}\end{array}$ & $\begin{array}{l}3.14, \mathrm{t} \\
(7.5)\end{array}$ & $\begin{array}{l}\text { 3.27, } \mathrm{AA}^{\prime} \mathrm{XX}^{\prime} \\
\left(J_{\mathrm{AX}} 12 J_{\mathrm{AX}^{\prime}} 5\right)\end{array}$ & $3.33^{c}$ & $\begin{array}{l}3.11, \mathrm{t} \\
(6.0)\end{array}$ & $\begin{array}{c}2.43, \mathrm{dt}(15.0,7.5) \\
2.06, \mathrm{ddd}(15.0,7.5,5.0)\end{array}$ & $\begin{array}{l}2.73, \mathrm{~m} \\
2.57, \mathrm{~m}\end{array}$ & $\begin{array}{l}3.35, \mathrm{t} \\
(6.0)\end{array}$ & $\begin{array}{c}3.37, \mathrm{t} \\
(6.0)\end{array}$ \\
\hline $\begin{array}{l}9 a \\
9 b\end{array}$ & $\begin{array}{l}3.39, \mathrm{t} \\
(7.5)\end{array}$ & $\begin{array}{c}3.73, \mathrm{AA}^{\prime} \mathrm{XX} X^{\prime} \\
\left(J_{\mathrm{AX}} 12 J_{\mathrm{AX}}{ }^{\prime}\right)\end{array}$ & $3.72, \mathrm{~m}$ & $\begin{array}{l}3.83, \mathrm{~m} \\
3.53, \mathrm{~m}\end{array}$ & $\begin{array}{c}3.58, \mathrm{dt}(15.0,7.5) \\
3.37^{\mathrm{c}}\end{array}$ & $\begin{array}{l}3.68, \mathrm{~m} \\
3.26, \mathrm{~m}\end{array}$ & $\begin{array}{l}3.29, \mathrm{t} \\
(6.0)\end{array}$ & $3.32^{c}$ \\
\hline $\begin{array}{c}11 \\
11^{\prime}\end{array}$ & $2.93, \mathrm{~s}$ & $3.33, \mathrm{~s}$ & $3.42, \mathrm{~s}$ & $\begin{array}{l}3.12, \mathrm{~s} \\
4.62, \mathrm{~m} \\
4.45, \mathrm{~m}\end{array}$ & $2.94, \mathrm{~s}$ & $\begin{array}{l}3.25, \mathrm{~s} \\
3.01, \mathrm{~s}\end{array}$ & - & \\
\hline 12 & - & $5.39, \mathrm{~s}$ & - & - & - & - & - & - \\
\hline $\mathrm{CH}_{3}-\mathrm{O}$ & - & - & - & - & - & - & - & $3.81, \mathrm{~s}$ \\
\hline
\end{tabular}

The molecular formula of 2 , isolated as a colorless amorphous solid, was deduced as $\mathrm{C}_{12} \mathrm{H}_{14} \mathrm{Br}_{2} \mathrm{~N}_{2} \mathrm{O}$ from the molecular ion at $\mathrm{m} / \mathrm{z} 360.9557[\mathrm{M}+\mathrm{H}]^{+}$, showing an isotopic pattern of two bromine atoms. While the ${ }^{1} \mathrm{H}$ NMR and ${ }^{13} \mathrm{C}$ NMR spectra were very similar to those of 9 , the signals corresponding to the $\mathrm{H}_{2}-9$ methylene and the two $\mathrm{N}$-methyls were strongly deshielded. Because 2 showed a molecular mass 16 amu higher than 9 , it was proposed to be the $N$-oxide analogue of 9. This assumption was confirmed by the presence of a fragment at $m / z 301.9008$ in HRMS/MS, revealing the loss of the $\mathrm{N}, \mathrm{N}$-dimethylamine- $\mathrm{N}$-oxide fragment. Thus, 2 was established as 5,6-dibromo- $N, N$-dimethyltryptamine- $N$-oxide. 
Table 2. ${ }^{13} \mathrm{C}$ NMR data $(150 \mathrm{MHz}), \delta_{\mathrm{C}}$ in ppm, type, in $\mathrm{CD}_{3} \mathrm{OD}$ for 1-7 and 9.

\begin{tabular}{ccccccccc}
\hline Position & $\mathbf{9}$ & $\mathbf{1}$ & $\mathbf{2}$ & $\mathbf{3}$ & $\mathbf{4}$ & $\mathbf{5}$ & $\mathbf{6}$ & $\mathbf{7}$ \\
\hline $\mathbf{2}$ & $126.8, \mathrm{CH}$ & $125.6, \mathrm{CH}$ & $126.7, \mathrm{CH}$ & $128.8, \mathrm{C}$ & $180.3, \mathrm{C}$ & $100.7, \mathrm{CH}$ & & \\
$\mathbf{3}$ & $109.7, \mathrm{C}$ & $107.4, \mathrm{C}$ & $110.1, \mathrm{C}$ & $106.3, \mathrm{C}$ & $75.3, \mathrm{C}$ & $88.4, \mathrm{C}$ & $198.9, \mathrm{C}$ & $199.1 . \mathrm{C}$ \\
$\mathbf{3 a}$ & $129.1, \mathrm{C}$ & $127.6, \mathrm{C}$ & $129.3, \mathrm{C}$ & $128.1, \mathrm{C}$ & $134.1, \mathrm{C}$ & $134.1, \mathrm{C}$ & $118.2, \mathrm{C}$ & $118.6, \mathrm{C}$ \\
$\mathbf{4}$ & $123.5, \mathrm{CH}$ & $122.1, \mathrm{CH}$ & $123.7, \mathrm{CH}$ & $123.7, \mathrm{CH}$ & $130.1, \mathrm{CH}$ & $129.8, \mathrm{CH}$ & $136.1, \mathrm{CH}$ & $131.1, \mathrm{CH}$ \\
$\mathbf{5}$ & $117.5, \mathrm{C}$ & $116.3, \mathrm{C}$ & $117.3, \mathrm{C}$ & $118.2, \mathrm{C}$ & $118.3, \mathrm{C}$ & $115.5, \mathrm{C}$ & $108.7, \mathrm{C}$ & $108.8, \mathrm{C}$ \\
$\mathbf{6}$ & $115.0, \mathrm{C}$ & $113.8, \mathrm{C}$ & $114.9, \mathrm{C}$ & $115.6, \mathrm{C}$ & $126.5, \mathrm{C}$ & $127.0, \mathrm{C}$ & $132.4, \mathrm{C}$ & $126.6, \mathrm{C}$ \\
$\mathbf{7}$ & $117.3, \mathrm{CH}$ & $116.1, \mathrm{CH}$ & $117.3, \mathrm{CH}$ & $117.3, \mathrm{CH}$ & $116.6, \mathrm{CH}$ & $116.3, \mathrm{CH}$ & $122.8, \mathrm{CH}$ & $147.7, \mathrm{C}$ \\
$\mathbf{7 a}$ & $137.8, \mathrm{CH}$ & $136.4, \mathrm{CH}$ & $137.8, \mathrm{C}$ & $138.0, \mathrm{C}$ & $142.9, \mathrm{C}$ & $149.7, \mathrm{C}$ & $152.4, \mathrm{C}$ & $146.1, \mathrm{C}$ \\
$\mathbf{8}$ & $21.5, \mathrm{CH}_{2}$ & $18.0, \mathrm{CH}_{2}$ & $20.0, \mathrm{CH}_{2}$ & $19.5, \mathrm{CH}_{2}$ & $32.6, \mathrm{CH}_{2}$ & $39.0, \mathrm{CH}_{2}$ & $36.6, \mathrm{CH}_{2}$ & $36.8, \mathrm{CH}_{2}$ \\
$\mathbf{9}$ & $58.8, \mathrm{CH}_{2}$ & $62.7, \mathrm{CH}_{2}$ & $70.9, \mathrm{CH}_{2}$ & $53.6, \mathrm{CH}_{2}$ & $54.4, \mathrm{CH}_{2}$ & $62.2, \mathrm{CH}_{2}$ & $36.0, \mathrm{CH}_{2}$ & $36.0, \mathrm{CH}_{2}$ \\
$\mathbf{1 1}$ & $43.5, \mathrm{CH}_{3}$ & $48.5, \mathrm{CH}_{3}$ & $57.6, \mathrm{CH}_{3}$ & $43.1, \mathrm{CH}_{3}$ & $43.8, \mathrm{CH}_{3}$ & $46.9, \mathrm{CH}_{3}$ & & \\
$\mathbf{1 1}$ & & $68.2, \mathrm{CH}_{2}$ & & $51.8, \mathrm{CH}_{2}$ & & & & \\
$\mathbf{1 2}$ & & & & & & & \\
$\mathbf{C H}_{3}-\mathrm{O}$ & & & & & & & & \\
\hline
\end{tabular}

Compound 3 was isolated as a colorless amorphous solid, showing a molecular ion at $m / z 342.9433$ $[\mathrm{M}+\mathrm{H}]^{+}$, corresponding to the molecular formula $\mathrm{C}_{12} \mathrm{H}_{12} \mathrm{Br}_{2} \mathrm{~N}_{2}$. The aromatic region of the ${ }^{1} \mathrm{H} N \mathrm{NR}$ spectrum was consistent with a 5,6-dibromosubstituted indole. However, the signal corresponding to $\mathrm{H}-2$ was missing when compared to $\mathbf{1}$ and $\mathbf{2}$, indicating this position was substituted. While only one nitrogenated methyl was evidenced in 3 at $\delta_{\mathrm{H}} 3.12\left(\mathrm{~s}, \mathrm{H}_{3}-11\right)$, other broad signals appeared in the ${ }^{1} \mathrm{H}$ NMR at $\delta_{\mathrm{H}} 4.62,4.45\left(\mathrm{H}_{2}-11^{\prime}\right), 3.83,3.53\left(\mathrm{H}_{2}-9\right)$ in addition to the signal of the methylene protons at $\delta_{\mathrm{H}} 3.11\left(\mathrm{t}, J=6 \mathrm{~Hz}, \mathrm{H}_{2}-8\right)$. The correlation spectroscopy (COSY) and heteronuclear single quantum coherence (HSQC) spectra were not helpful to solve the structure due to the broadening of the signals of the two first methylene groups. Gratifyingly, key H-11/C-11' and C-9 HMBC correlations were highly informative to place the two methylene groups next to the tertiary amine. The only possibility to comply with the molecular formula and the substitution at C-2 was therefore to envisage the presence of a $N$-methyl substituted tetrahydro- $\beta$-carboline. Broadening of the signals at C-9 and C- $11^{\prime}$ is easily explained as the protonated tertiary amine becomes chiral in the acidic medium used during the purification process [28]. This is the first report of the 6,7-dibromo-2-methyltetrahydro- $\beta$-carboline.

Compound 4 was obtained as a yellow amorphous solid, and its molecular formula $\mathrm{C}_{12} \mathrm{H}_{14} \mathrm{Br}_{2} \mathrm{~N}_{2} \mathrm{O}_{2}$ was deduced from the protonated adduct at $m / z 376.9503[\mathrm{M}+\mathrm{H}]^{+}$in its HRMS spectrum. The ${ }^{1} \mathrm{H}$ NMR spectrum again revealed the presence of a 5,6-dibromosubstituted indole ring system but, as in 3 , the signal corresponding to $\mathrm{H}-2$ was absent in 4 . The ${ }^{13} \mathrm{C}$ NMR spectrum revealed the presence of two new non-protonated carbons: A carbonyl group at $\delta_{\mathrm{C}} 180.3$ (qC,C-2) and an oxygenated sp $\mathrm{p}^{3}$ carbon at $\delta_{\mathrm{C}}$ 75.3 (qC, C-3). A key H-4/C-3 HMBC correlation placed the non-protonated oxygenated carbon at C-3, while a unique $\mathrm{H}-8 \mathrm{a} / \mathrm{C}-2 \mathrm{HMBC}$ correlation was consistent with the carbonyl group at C-2. The $\mathrm{C}-2 / \mathrm{C}-3$ bond of the indole ring of 4 was therefore oxidized into a 3-hydroxyindolin-2-one, and the chemical shifts of the carbons at both positions were in accordance with those of analogues in this series [29]. Two non-equivalent methylenes coupled in the ABMX system at $\delta_{\mathrm{H}} 2.43(\mathrm{dt}, J=15.0,7.5 \mathrm{~Hz}, \mathrm{H}-8 \mathrm{a})$, 2.06 (ddd, $J=15.0,7.5,5.0 \mathrm{~Hz}, \mathrm{H}-8 \mathrm{~b}$ ), and 3.58 (dt, $J=15.0,7.5 \mathrm{~Hz}, \mathrm{H}-9 \mathrm{a}), 3.37$ (m, H-9b), therefore confirming the presence of a chiral center at C-3. The absolute configuration at C-3 was assessed by comparison between the experimental and calculated electronic circular dichroism (ECD) spectra. The ECD spectra of both enantiomers of 4 were calculated using time-dependent density functional theory (TDDFT) at the B3LYP/6-311+G(d,p)//B3LYP/6-31G(d) level of theory. Not surprisingly, the calculated ECD spectrum of the $3 R$ enantiomer matched the experimental spectrum of 4 , as this configuration is also found for most of the natural products containing a 3-hydroxyindolin-2-one (Figure 2). Finally, 4 was named narrabeenamine A. 


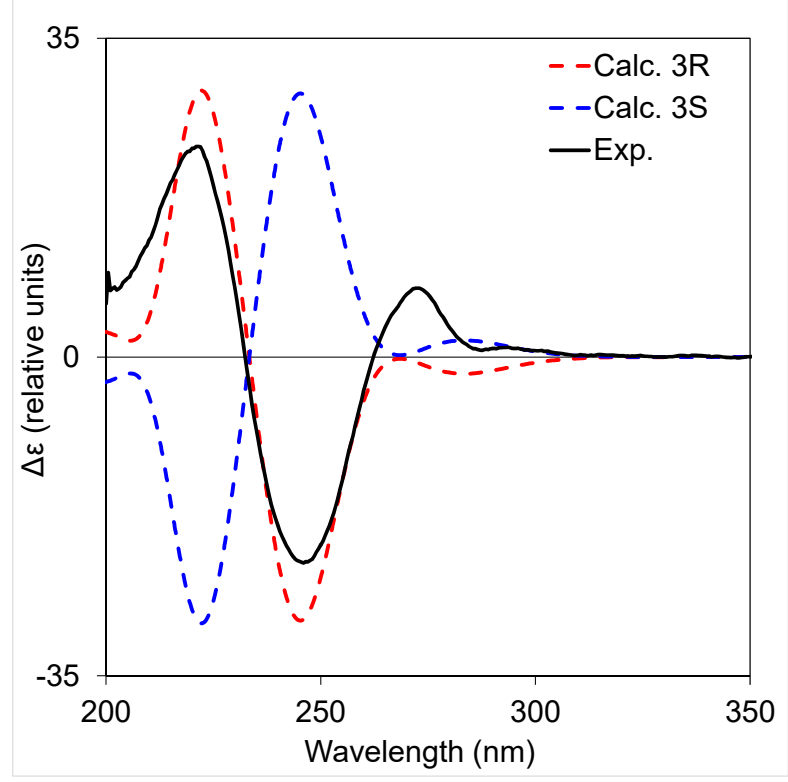

Figure 2. Comparison between the calculated and experimental electronic circular dichroism (ECD) spectra of both enantiomers of 4 .

Compound 5 was isolated as a yellow amorphous solid, and its molecular formula $\mathrm{C}_{12} \mathrm{H}_{15} \mathrm{Br}_{2} \mathrm{~N}_{2} \mathrm{O}$ was deduced from the ion peak of the HRMS spectrum at $\mathrm{m} / \mathrm{z} 360.9551[\mathrm{M}]^{+}$. Like 3 and 4 , the 5,6-dibromosubstituted benzene ring system was deduced from the two aromatic proton singlets at $\delta_{\mathrm{H}}$ $7.62(\mathrm{~s}, \mathrm{H}-4)$ and $7.14(\mathrm{~s}, \mathrm{H}-7)$, but the signal corresponding to $\mathrm{H}-2$ was again absent. The presence of a non-protonated oxygenated carbon signal at $\delta_{C} 88.4$ (qC, C-3), together with the key H-4/C-3 HMBC correlation, suggested the presence of a hydroxyl group at C-3. Since no carbonyl signal was observed in the ${ }^{13} \mathrm{C}$ NMR spectrum, a different substitution pattern at $\mathrm{C}-2$ was deduced for $\mathbf{5}$ when compared to 4. The ${ }^{1} \mathrm{H}$ and ${ }^{13} \mathrm{C}$ NMR spectra of 5 revealed the presence of one methine group with the proton and carbon signals at $\delta_{\mathrm{H}} 5.18(\mathrm{~s}, \mathrm{H}-2)$ and $\delta_{\mathrm{C}} 100.7(\mathrm{CH}, \mathrm{C}-2)$ and two non-equivalent $N$-methyl groups at $\delta_{\mathrm{H}} 3.25\left(\mathrm{~s}, \mathrm{H}_{3}-11\right)$ and $3.01\left(\mathrm{~s}, \mathrm{H}_{3}-11^{\prime}\right)$. Moreover, H-2/C3, C-7a, C-9, and H-11/C-2, C-9 HMBC correlations revealed the presence of a third ring system containing the aminal functional group of a hexahydropyrrolo[2,3-b] indole skeleton (Figure 3). Comparison of the NMR data of 5 with those of other natural products in this series confirmed our assumption and $\mathbf{5}$ was named narrabeenamine B [30].

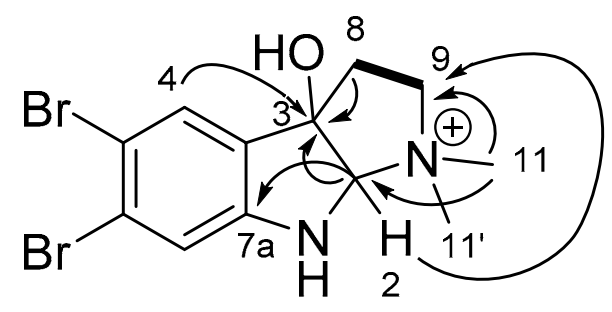

Figure 3. Key correlation spectroscopy COSY (bold) and heteronuclear multiple bond correlation HMBC (arrows from $\mathrm{H}$ to C) for narrabeenamine B (5). 
The absolute configurations at the C-2 and C-3 chiral centers were assessed by comparison between the experimental and calculated ECD spectra of the 4 possible diastereoisomers. Indeed, the NOESY spectrum did not allow the assignment of the relative configurations even if the spectrum was run in DMSO- $d_{6}$. The ECD spectra of the four possible configurations of 5 were therefore calculated using TDDFT at the B3LYP/6-311+G(d,p)//B3LYP/6-31G(d) level of theory. As in 4, the negative Cotton effect at $250 \mathrm{~nm}$ suggested a $3 R$ configuration. Comparison between the calculated ECD spectra of both $(2 S, 3 R)$ and $(2 R, 3 R)$ epimers and the experimental ECD spectrum of 5 evidenced the presence of an additional key Cotton effect of a $\pi \rightarrow \pi^{*}$ transition at approximately $290 \mathrm{~nm}$, which is associated with the configuration at C-2. The negative Cotton effect observed at $310 \mathrm{~nm}$ in the experimental spectrum of 5 was in accordance with the $(2 S, 3 R)$ relative configurations (Figure 4$)$.

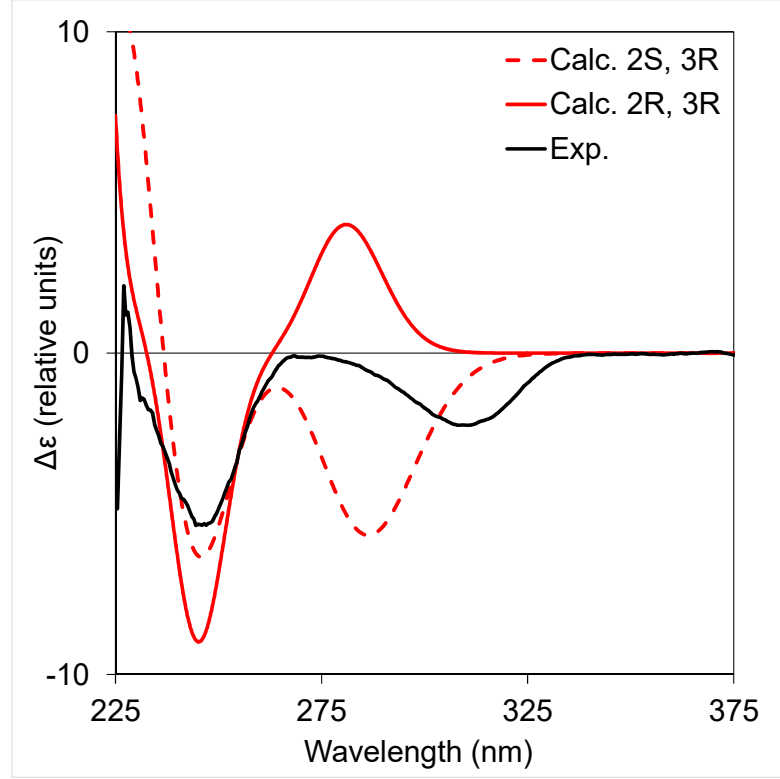

Figure 4. Comparison of the calculated and experimental ECD spectra of the two epimers of 5 at C-2.

The molecular formula $\mathrm{C}_{9} \mathrm{H}_{10} \mathrm{Br}_{2} \mathrm{~N}_{2} \mathrm{O}$ of 6 , a yellow amorphous solid, was deduced from the ion at $m / z 320.9239[\mathrm{M}+\mathrm{H}]^{+}$of its HRMS spectrum. The ${ }^{1} \mathrm{H}$ NMR spectrum of 6 exhibited two aromatic proton signals at $\delta_{\mathrm{H}} 7.98(\mathrm{~s}, \mathrm{H}-4)$ and $7.19(\mathrm{~s}, \mathrm{H}-7)$, suggesting again the presence of the 5,6-dibromobenzene ring of the indole ring system and two coupled methylene protons. However, the signals corresponding to $\mathrm{H}-2$ and the methyls were absent, while the presence of a ketone was evidenced by the signal at $\delta_{C} 198.9$ (qC, C-3) in the ${ }^{13} \mathrm{C}$ NMR spectrum. The key H-4/C3, C-3a, C-5, C-6, C-7a HMBC correlations placed the ketone at the ortho position of the aromatic amino group (C-3 respecting the previous numbering), and the ethylene moiety connected the ketone to another primary amine. Cleavage of the C-2/C-3 bond and loss of the resulting formamide were therefore proposed in order to match the molecular formula. This skeleton is also found in natural products, as exemplified in 5,6-dibromokynuramine [22].

Compound 7 was obtained as a yellow amorphous solid and showed a main ion at $\mathrm{m} / \mathrm{z} 350.9344$ $[\mathrm{M}+\mathrm{H}]^{+}$in its HRMS spectrum, leading to the molecular formula $\mathrm{C}_{10} \mathrm{H}_{12} \mathrm{Br}_{2} \mathrm{~N}_{2} \mathrm{O}_{2}$. The ${ }^{1} \mathrm{H} \mathrm{NMR}$ and HSQC spectra revealed the presence of one aromatic proton signal at $\delta_{\mathrm{H}} 7.87(\mathrm{~s}, \mathrm{H}-4)$ and a signal of a methoxy group at $\delta_{\mathrm{H}} 3.81\left(\mathrm{~s}, \mathrm{CH}_{3} \mathrm{O}-\right)$, while the other signals were very similar to those of 6 . The location of the methoxy group at $\mathrm{C}-7$ of the aromatic ring was inferred from the key $\underline{\mathrm{C}}_{3}-\mathrm{O} / \mathrm{C}-7 \mathrm{HMBC}$ correlation. Therefore, 7 is the methoxylated analogue of 6 at C-7. 
Compound 8 was isolated as a colorless amorphous solid with a molecular formula $\mathrm{C}_{10} \mathrm{H}_{13} \mathrm{Br}_{2} \mathrm{NO}$ as deduced from the $[\mathrm{M}+\mathrm{H}]^{+}$ion at $m / z$ 321.9447. The ${ }^{1} \mathrm{H}$ NMR spectrum of 8 did not correspond to an indole derivative, as the only aromatic signal at $\delta_{\mathrm{H}} 7.55\left(\mathrm{~s}, \mathrm{H}_{2}-2 / 6\right)$ was integrated for two protons. The symmetry for the aromatic ring of a dibrominated compound quickly led us to propose a tyramine derivative for 8 . The analogy with the known 3,5-dibromo-4-methoxytyramine (16) was evident, and the additional nitrogenated methyl observed at $\delta_{\mathrm{H}} 2.72\left(\mathrm{~s}, \underline{\mathrm{C}}_{3} \mathrm{NH}-\right)$ revealed that 8 is indeed the new $N$-methyl analogue of 16 .

\subsection{Biological Assays}

Since human neuroblastoma SH-SY5Y and microglia BV2 cells are commonly used for biological studies of neuroinflammation and neuroprotection [31,32], all isolated brominated alkaloids were then tested in these two cellular models. First, the effects of these compounds on cell viability were determined using the 3-(4,5-dimethylthiazol-2-yl)-2,5-diphenyltetrazolium bromide (MTT) assay. Cells were treated with different concentrations of compounds $(0.001,0.01,0.1,1$, and $10 \mu \mathrm{M})$ for $24 \mathrm{~h}$. None of the tested compounds induced cytotoxic effects on BV2 cells at any concentrations tested. Furthermore, among the 18 compounds tested on SH-SY5Y neuroblastoma cells, only 3 at $10 \mu \mathrm{M}$ reduced cell viability up to $60 \%(p<0.05)$ versus control cells. To evaluate the neuroprotective effects of these compounds, tert-butyl hydroperoxide (TBHP) was used to induce oxidative damage, and the antioxidant vitamin $\mathrm{E}$ was used as a control for neuroprotective effects. As shown in Figure 5, the oxidative damage induced after $6 \mathrm{~h}$ of treatment in the presence of TBHP significantly reduced SH-SY5Y cell viability $(50 \%)$ compared with the control group $(p<0.001)$. This effect was reduced in the presence of vitamin E, restoring cell survival to $80 \%(p<0.05)$. In a similar way, some of the brominated alkaloids protected SH-SY5Y cells against TBHP-induced oxidative damage, avoiding cell death. Compound 5 reduced cellular death at the same level as vitamin $\mathrm{E}$ and therefore showed a protective effect at 0.01 and $0.1 \mu \mathrm{M}(p<0.05$, Figure 5). Furthermore, the same effect was observed in the presence of 7 at all concentrations tested ( $p<0.05$, Figure 5). Finally, the most potent activity was observed after treatment with 15, since neuronal death induced by TBHP was almost totally inhibited, having a stronger neuroprotective effect than vitamin $\mathrm{E}(p<0.05$, Figure 6$)$. Compounds 9, 11, 12, and 18 prevented cell death in a dose-dependent manner, being statistically significant at the highest concentrations tested ( $p<0.05$, Figure 6). Finally, $\mathbf{1 0}$ and $\mathbf{1 3}$ reduced TBHP-induced cell death at 0.1 and $1 \mu \mathrm{M}(p<0.05$, Figure 5$)$. The rest of the tested compounds did not show any protective effect in SH-SY5Y cells (Figure 5).

To better assess the potential of the nine neuroprotective compounds, their anti-inflammatory activity was tested in activated microglia cells. The activation of microglia leads to the release of pro-inflammatory mediators such as nitric oxide (NO) and the overproduction of these mediators cause oxidative damage in neurons [33]. Therefore, to simulate inflammatory conditions, microglia BV2 cells were activated with lipopolysaccharide (LPS). As shown in Figure 6, when cells were treated with LPS, NO release was doubled compared to control cells $(p<0.001)$. Nevertheless, in the presence of $\mathbf{1 1}$ and $15(0.1$ and $1 \mu \mathrm{M})$ or $18(1 \mu \mathrm{M})$, the NO release was significantly inhibited $(p<0.01)$. Surprisingly, this effect was also observed after incubation in the presence of $0.1 \mu \mathrm{M}$ of $\mathbf{9}, \mathbf{1 0}, \mathbf{1 2}$, and $\mathbf{1 3}$ but not at $1 \mu \mathrm{M}$. In the same conditions, 5 and $\mathbf{7}$ did not show any significant activity on the microglia BV2 cells. In both the BV2 and SH-SY5Y cellular models, some brominated alkaloids of this family possess interesting properties in neuroinflammation and neuroprotection. 

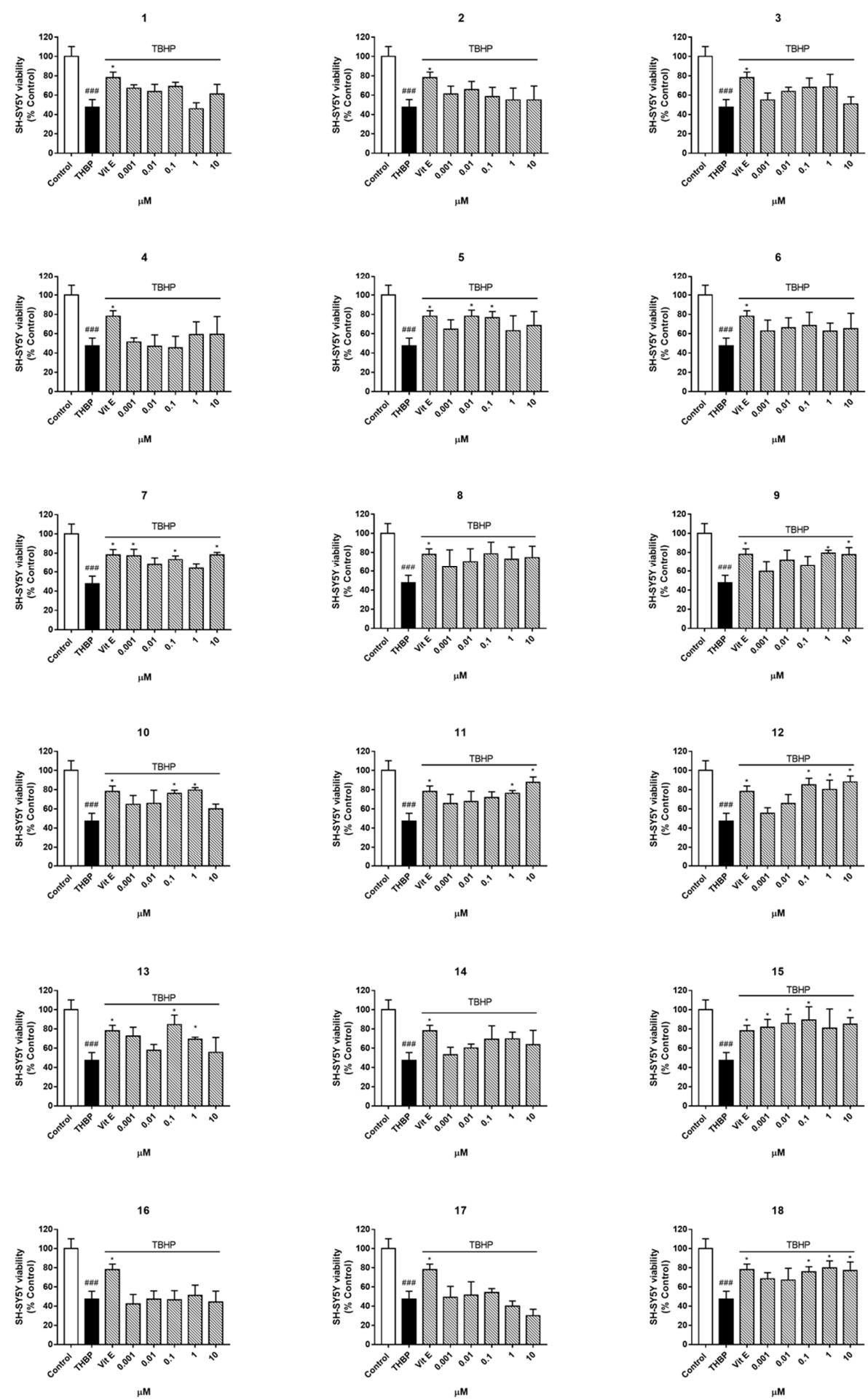

Figure 5. Effect of brominated alkaloids on oxidative damage in neuroblastoma SH-SY5Y cell line. Cells were treated with compounds $(0.001,0.01,0.1,1$, and $10 \mu \mathrm{M})$ in the presence of tert-butylhydroperoxide (TBHP) at $65 \mu \mathrm{M}$ for $6 \mathrm{~h}$. Cell viability was determined using 3-(4,5-dimethylthiazol-2-yl)-2,5-diphenyltetrazolium bromide (MTT) assay. Data are represented in percentage of cell control, being the result of mean absorbance \pm SEM of three independent experiments performed in triplicate. TBHP-treated cells were compared with cells treated with compounds plus TBHP by ANOVA followed by post hoc Dunnett's test. * $p<0.05$ or TBHP-treated cells versus untreated cells \#\#\# $p<0.001$. 


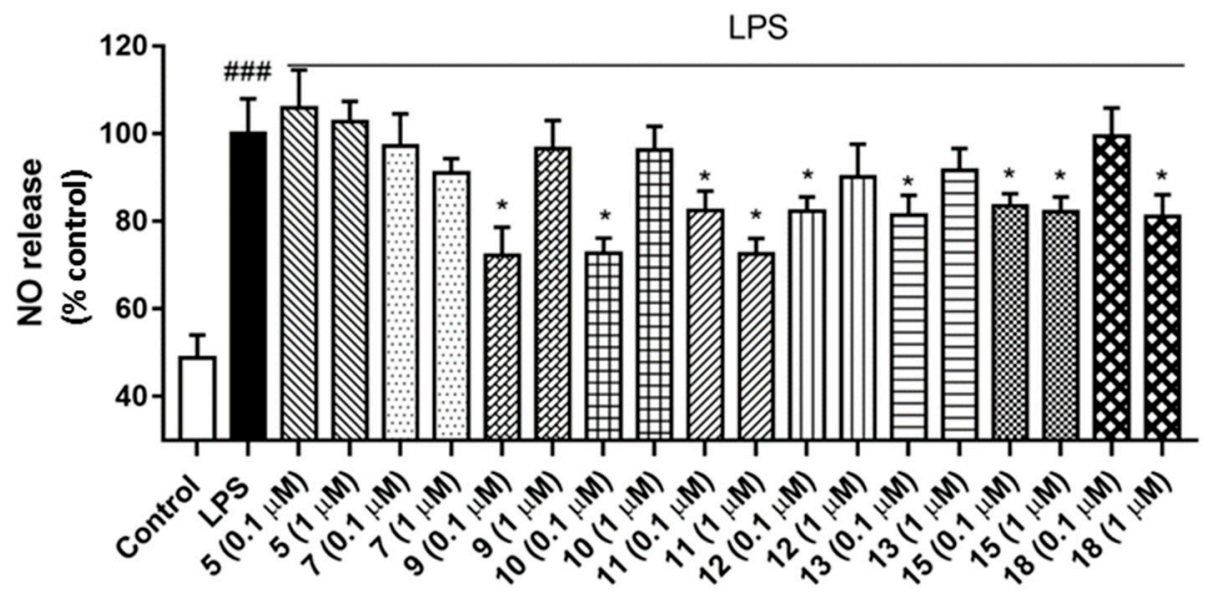

Figure 6. Effects of brominated alkaloids on nitric oxide (NO) release in BV2 microglia cell line. Cells were treated with $5,7,9,10,11,12,13,15$, and 18 at 0.1 and $1 \mu \mathrm{M}$ for $1 \mathrm{~h}$ before the stimulation with lipopolysaccharide (LPS) at $500 \mathrm{ng} / \mathrm{mL}$ for 24 hours. NO release was determined using Griess reagent. Data are represented in percentage of cells treated with LPS, being the result of mean fluorescence intensity \pm SEM of three independent experiments done in duplicate. LPS-treated cells were compared with cells treated with compounds plus LPS by ANOVA followed by post hoc Dunnett's test. ${ }^{*} p<0.05$ or LPS-treated cells versus untreated cells \#\#\# $p<0.001$.

\subsection{Biosynthetic Considerations}

Both bromotryptamine and bromotyramine families of alkaloids found in the Pacific sponge Narrabeena nigra mirror the high potential for marine biodiscovery of sponges found around the Futuna Islands. A microbial origin is likely to be involved in the biosynthesis of these compounds, as analogues of these simple brominated aromatic alkaloids were also found in other groups of invertebrates. Among the five different classes of biogenic metabolites of the bromotryptophan family, the oxindole moiety was indeed reported in the convolutamydines, and the pyrroloindole skeleton in the flustramines, both classes of compounds isolated from bryozoans [34-38]. The $\beta$-carboline moiety has already been found in bryozoans [39] and marine sponges from the genus Hyrtios [40]. The quinolone 15 was previously described in the sponge Clathria basilana and in a bryozoan [41,42], while the kynuramines, as exemplified by 6, were isolated in an undescribed sponge from the Red Sea [22]. Additionally, the known tryptamine derivatives $\mathbf{9 - 1 3}$ have been found in marine invertebrates such as gorgonians [19], tunicates [20], and different sponges of the genera Ancorina [43], Geodia [21], Jaspis [44], Verongula [15], Hyrtios [14,45], Aplysina [46], but mostly in Smenospongia [16-18]. The known tyramines 16-18 have been already described in verongiid sponges, [24,47,48] and in an ascidian [23]. Even though both families of compounds were found in N. nigra, the majority are bromotryptophan metabolites that are chemotaxonomically related to Dictyoceratida sponges, whereas the bromotyrosine derivatives are associated with the order Verongiida.

Due to the outstanding diversity of bromotryptamine derivatives isolated in this sponge, we postulate simple interconnections among all the isolated metabolites through metabolic transformations that include methylation and different types of oxidation of the indole nucleus (Scheme 1). 


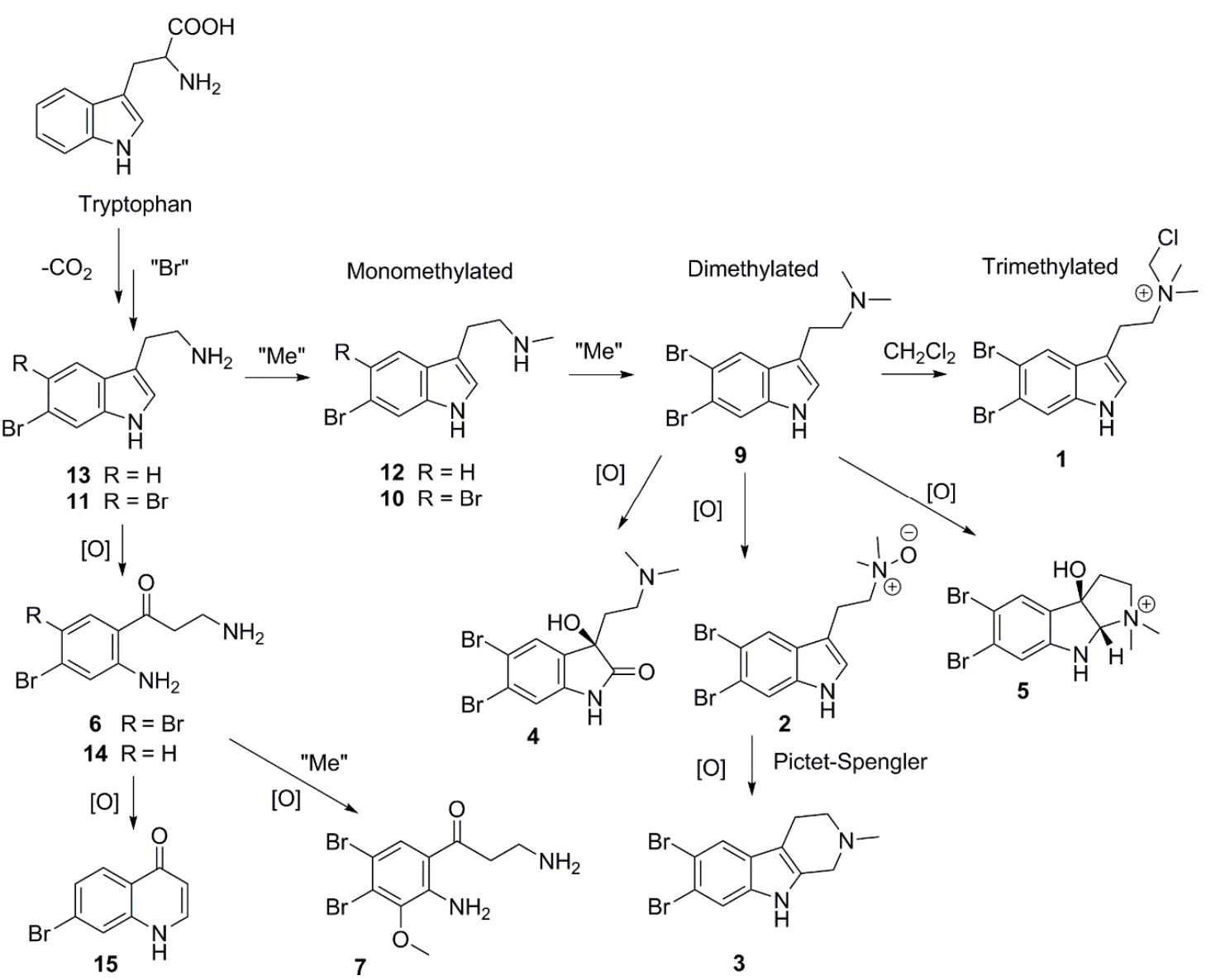

Scheme 1. Biosynthetic hypothesis for the formation of the bromotryptophan alkaloids isolated from the sponge $N$. nigra.

To further expand the chemical diversity in this family, the web server Metwork [49] performing an in silico metabolite anticipation was used to assess the presence of minor metabolites involved in this metabolic pathway. As expected, some minor metabolites were identified after comparison of the experimental with calculated MS/MS spectra. These compounds (in orange in Figure 7), which are slightly different from the isolated compounds, could correspond to some biosynthetic intermediates. This is especially true for the formylated compound at $\mathrm{m} / \mathrm{z} 271.0076$ resulting from the oxidative cleavage of 6-bromotryptamine (14), which was recently elucidated biosynthetically [50]. Gratifyingly, the cosines of most of the proposed structures are all above 0.5 , therefore expressing a high level of confidence (see Supplementary Information) [51]. The proposed structures are also in perfect agreement with the metabolome consistency, using simple and already confirmed biosynthetic transformations [52]. 


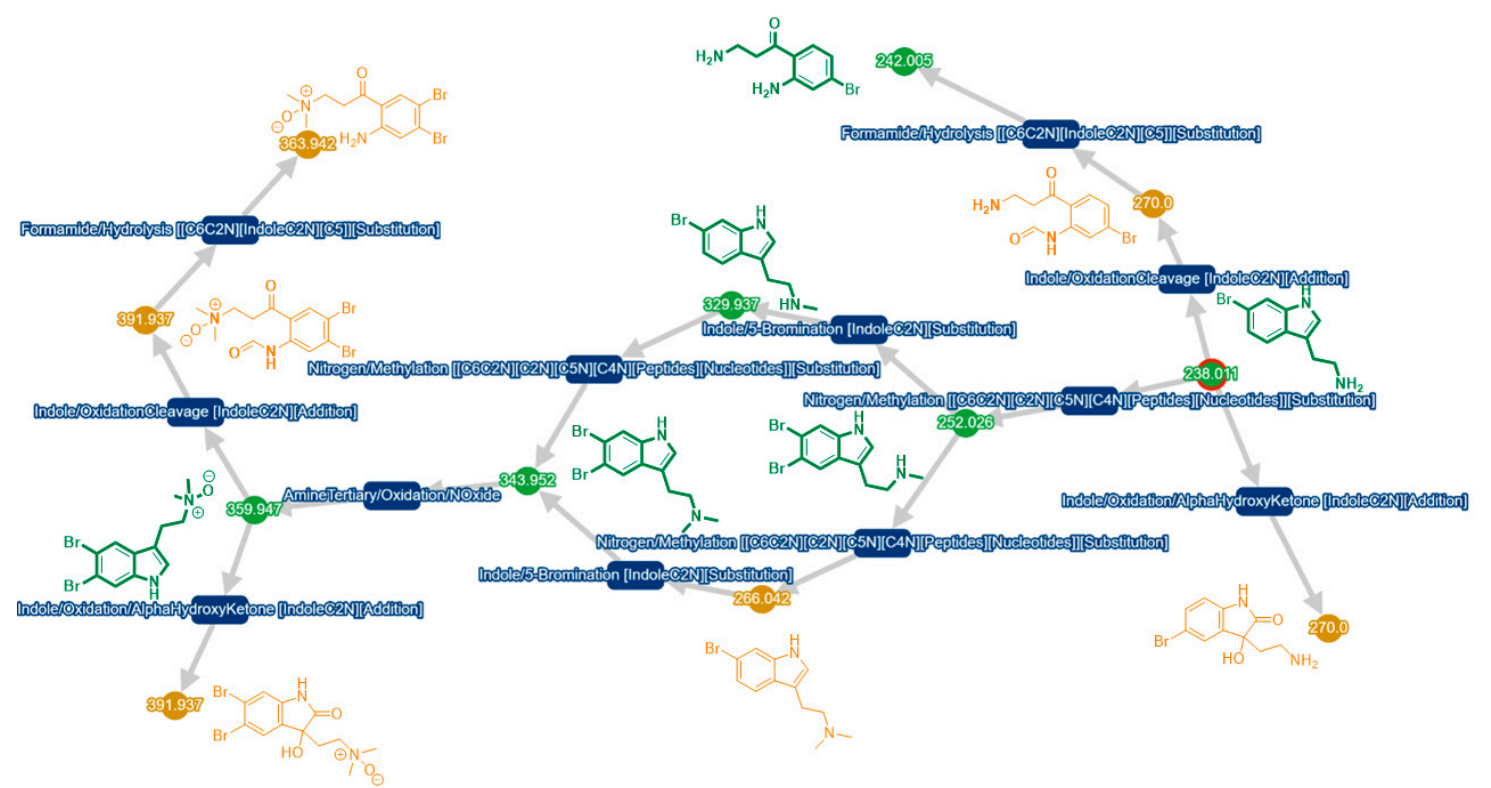

Figure 7. In silico metabolization network of the bromotryptamine derivatives present in the fraction of the sponge N. nigra. In green are the isolated compounds and in orange, the anticipated structures of minor analogues proposed by the webserver MetWork v0.3.5, Paris [49].

\section{Materials and Methods}

\subsection{General Experimental Procedures}

Optical rotation measurements were performed at the $\mathrm{Na}$ D line $(589.3 \mathrm{~nm})$ with a $5 \mathrm{~cm}$ cell at $20^{\circ} \mathrm{C}$ on a UniPol L1000 polarimeter (Schmidt + Haensch, Berlin, Germany). UV and ECD data were obtained on ChirascanTM V100 (Applied Photophysics, Leatherhead, UK). NMR experiments were performed on an Inova $500 \mathrm{MHz}$ spectrometer (Varian, Palo Alto, CA, USA) and on a $600 \mathrm{MHz}$ spectrometer (Agilent, Santa Clara, CA, USA). Chemical shifts were referenced in ppm to the residual solvent signals $\left(\mathrm{CD}_{3} \mathrm{OD}\right.$, at $\delta_{\mathrm{H}} 3.31$ and $\delta_{\mathrm{C}} 49.00 \mathrm{ppm}$; DMSO- $d_{6}$, at $\delta_{\mathrm{H}} 2.49$ and $\left.\delta_{\mathrm{C}} 39.5 \mathrm{ppm}\right)$. High-resolution mass spectra were obtained with a mass spectrometer UHPLC-HRMS (Agilent 6540, Santa Clara, CA, USA). Purifications were performed using several HPLC-DAD: Jasco (Tokyo, Japan) equipped with PU-2087 pump and UV-2075 detector (preparative), Waters 2690 (Milford, MA, USA) equipped with UV detector 2487 (semipreparative and analytical) and Agilent 1260 (Santa Clara, CA, USA) (analytical).

\subsection{Animal Material.}

The specimen of Narrabeena nigra Kim and Sim 2010 was collected at $8 \mathrm{~m}$ depth around the Alofi Island coast $\left(14^{\circ} 20^{\prime} 30^{\prime \prime}\right.$ S , $178^{\circ} 04^{\prime} 53^{\prime \prime}$ W), in December 2016, during the Tara Pacific expedition. A fragment was fixed with EtOH for taxonomic studies, while the rest of the sample was frozen at $-80^{\circ} \mathrm{C}$ and freeze-dried for chemical studies. Voucher specimen $n^{\circ} 161213 \mathrm{Fu} 06-01$ is stored at NUIG (National University of Ireland, Galway, Ireland).

\subsection{Extraction and Purification}

The lyophilized and ground sponge $(66.8 \mathrm{~g})$ was extracted with $\mathrm{MeOH} / \mathrm{CH}_{2} \mathrm{Cl}_{2}$ at room temperature under sonication $(1: 1 ; 3 \times 400 \mathrm{~mL}, 5 \mathrm{~min})$, and the solution was evaporated under reduced pressure. The dried extract $(7.27 \mathrm{~g})$ was sequentially fractionated in five fractions by flash silica C-18 VLC with solvents of decreasing polarity: (1) $\mathrm{H}_{2} \mathrm{O}$; (2) $\mathrm{H}_{2} \mathrm{O} / \mathrm{MeOH}$ (1:1); (3) $\mathrm{MeOH}$; (4) $\mathrm{MeOH} / \mathrm{CH}_{2} \mathrm{Cl}_{2}$ (1:1); and (5) $\mathrm{CH}_{2} \mathrm{Cl}_{2}$.

Fraction 2 (2.36 g) was purified by repeated semi-preparative reversed phase (RP)-HPLC (Waters SymmetryPrep C18, $7 \mu \mathrm{m} ; 7.8 \times 300 \mathrm{~mm}$; flow rate: $3.5 \mathrm{~mL} / \mathrm{min}$; UV detection: $210 \mathrm{~nm}$ ), using a 
gradient of solvents $\mathrm{H}_{2} \mathrm{O}: \mathrm{CH}_{3} \mathrm{CN} / 0.1 \%$ TFA (80:20, $5 \mathrm{~min}$; ramp to 70:30 over $20 \mathrm{~min}$; 70:30 for $5 \mathrm{~min}$ ), which led to 10 peaks (F2P1-F2P10), including $4\left(t_{\mathrm{R}}=15.8 \mathrm{~min}, 1.95 \mathrm{mg}, 2.92 \times 10^{-5} \% \mathrm{w} / \mathrm{w}\right), \mathbf{9}\left(t_{\mathrm{R}}=\right.$

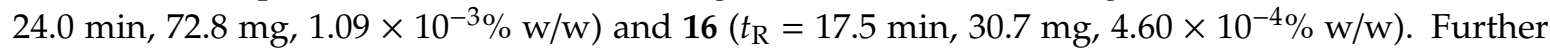
purification of F2P1 (Waters XSelect HSS T3, $5 \mu \mathrm{m} ; 4.6 \times 250 \mathrm{~mm}$; flow rate: $1 \mathrm{~mL} / \mathrm{min}$; UV detection: $210 \mathrm{~nm}$ ) with an isocratic solvent composition of $\mathrm{H}_{2} \mathrm{O}: \mathrm{CH}_{3} \mathrm{CN} / 0.1 \%$ TFA (82:18), led to $17\left(t_{\mathrm{R}}=18.7\right.$ $\left.\mathrm{min}, 1.23 \mathrm{mg}, 1.84 \times 10^{-5} \% \mathrm{w} / \mathrm{w}\right)$ and $\mathbf{1 8}\left(t_{\mathrm{R}}=14.9 \mathrm{~min}, 1.50 \mathrm{mg}, 2.25 \times 10^{-5} \% \mathrm{w} / \mathrm{w}\right)$. The purification of F2P5 (Waters Xselect Phenyl-hexyl, $5 \mu \mathrm{m} ; 4.6 \times 250 \mathrm{~mm}$; flow rate: $1 \mathrm{~mL} / \mathrm{min}$; UV detection: $210 \mathrm{~nm}$ ) using an isocratic solvent system $\mathrm{H}_{2} \mathrm{O}: \mathrm{CH}_{3} \mathrm{CN} / 0.1 \%$ TFA (86:14) provided $6\left(t_{\mathrm{R}}=36.5 \mathrm{~min}, 3.92 \mathrm{mg}\right.$, $\left.5.87 \times 10^{-5} \% \mathrm{w} / \mathrm{w}\right)$ and $16\left(t_{\mathrm{R}}=31.5 \mathrm{~min}, 3.25 \mathrm{mg}, 4.87 \times 10^{-5} \% \mathrm{w} / \mathrm{w}\right)$ and the separation of F2P9 (3.87 $\mathrm{mg}$ ) (Waters Xselect Phenyl-hexyl, $5 \mu \mathrm{m} ; 4.6 \times 250 \mathrm{~mm}$; flow rate: $1 \mathrm{~mL} / \mathrm{min}$; UV detection: $210 \mathrm{~nm}$ ) with a gradient of solvents $\mathrm{H}_{2} \mathrm{O}: \mathrm{CH}_{3} \mathrm{CN} / 0.1 \%$ TFA (80:20, $5 \mathrm{~min}$; ramp to $50: 50$ over $\left.30 \mathrm{~min}\right)$ led to $9\left(t_{\mathrm{R}}\right.$ $\left.=13.8 \mathrm{~min}, 1.50 \mathrm{mg}, 2.25 \times 10^{-5} \% \mathrm{w} / \mathrm{w}\right), \mathbf{1 0}\left(t_{\mathrm{R}}=13.2 \mathrm{~min}, 1.32 \mathrm{mg}, 1.98 \times 10^{-5 \% \mathrm{w}} / \mathrm{w}\right)$ and $\mathbf{1 1}\left(t_{\mathrm{R}}=\right.$ $\left.12.5 \mathrm{~min}, 0.91 \mathrm{mg}, 1.36 \times 10^{-5} \% \mathrm{w} / \mathrm{w}\right)$.

Fraction $3(0.38 \mathrm{~g})$ was purified using the same conditions as those used for fraction 2, and 10 peaks were obtained (F3P1-F3P10), including $2\left(t_{\mathrm{R}}=29.8 \mathrm{~min}, 1.99 \mathrm{mg}, 2.98 \times 10^{-5} \% \mathrm{w} / \mathrm{w}\right), 9\left(t_{\mathrm{R}}=22.5 \mathrm{~min}\right.$, $\left.37.2 \mathrm{mg}, 5.57 \times 10^{-4} \% \mathrm{w} / \mathrm{w}\right)$, and $18\left(t_{\mathrm{R}}=9.2 \mathrm{~min}, 2.48 \mathrm{mg}, 3.71 \times 10^{-5} \% \mathrm{w} / \mathrm{w}\right)$. Then, the purification of F3P2 (Waters Xselect Phenyl-hexyl, $5 \mu \mathrm{m} ; 4.6 \times 250 \mathrm{~mm}$; flow rate: $1 \mathrm{~mL} / \mathrm{min}$; UV detection: $210 \mathrm{~nm}$ ) was done using an isocratic system of $\mathrm{H}_{2} \mathrm{O}: \mathrm{CH}_{3} \mathrm{CN} / 0.1 \%$ TFA (87:13) led to $14\left(t_{\mathrm{R}}=14.4 \mathrm{~min}, 0.69 \mathrm{mg}\right.$,

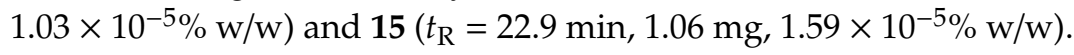

The combined F2P4 and F3P4 (6.79 mg) was further purified (Waters Xselect Phenyl-hexyl, $5 \mu \mathrm{m}$; $4.6 \times$ $250 \mathrm{~mm}$; flow rate: $1 \mathrm{~mL} / \mathrm{min}$; UV detection: $210 \mathrm{~nm}$ ) with $\mathrm{H}_{2} \mathrm{O}: \mathrm{CH}_{3} \mathrm{CN} / 0.1 \%$ TFA (86:14), which gave $\mathbf{5}\left(t_{\mathrm{R}}=34.0 \mathrm{~min}, 1.74 \mathrm{mg}, 2.61 \times 10^{-5} \% \mathrm{w} / \mathrm{w}\right), \mathbf{1 2}\left(t_{\mathrm{R}}=31.5 \mathrm{~min}, 1.20 \mathrm{mg}, 1.80 \times 10^{-5} \% \mathrm{w} / \mathrm{w}\right)$, and $\mathbf{1 3}\left(t_{\mathrm{R}}\right.$ $\left.=26.5 \mathrm{~min}, 1.32 \mathrm{mg}, 1.98 \times 10^{-5} \% \mathrm{w} / \mathrm{w}\right)$. The combined F2P7 and F3P7 $(6.02 \mathrm{mg})$ was further purified (Waters Xselect Phenyl-hexyl, $5 \mu \mathrm{m}$; $4.6 \times 250 \mathrm{~mm}$; flow rate: $1 \mathrm{~mL} / \mathrm{min}$; UV detection: $210 \mathrm{~nm}$ ) with $\mathrm{H}_{2} \mathrm{O}: \mathrm{CH}_{3} \mathrm{CN} / 0.1 \%$ TFA (82:18), affording $7\left(t_{\mathrm{R}}=23.9 \mathrm{~min}, 2.66 \mathrm{mg}, 3.98 \times 10^{-5} \% \mathrm{w} / \mathrm{w}\right), 8\left(t_{\mathrm{R}}=19.9 \mathrm{~min}\right.$,

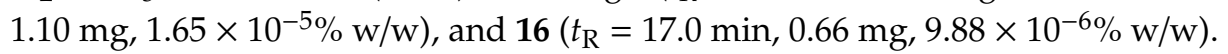

Fraction 4 (1.03 g) was purified by RP-HPLC (Waters Xselect Prep C18, $5 \mu \mathrm{m} ; 19 \times 250 \mathrm{~mm}$; flow rate: $12 \mathrm{~mL} / \mathrm{min}$; UV detection: $210 \mathrm{~nm}$ ), using an isocratic solvent $\mathrm{H}_{2} \mathrm{O}: \mathrm{CH}_{3} \mathrm{CN} / 0.1 \%$ TFA (70:30). Further purification of combined F4P6 and F4P7 (10.66 mg) (Waters Xselect Phenyl-hexyl, $5 \mu \mathrm{m} ; 4.6 \times 250 \mathrm{~mm}$; flow rate: $1 \mathrm{~mL} / \mathrm{min}$; UV detection: $210 \mathrm{~nm})$ using $\mathrm{H}_{2} \mathrm{O}: \mathrm{CH}_{3} \mathrm{CN} / 0.1 \%$ TFA (75:25) led to $1\left(t_{\mathrm{R}}=18.5\right.$ $\left.\min , 0.92 \mathrm{mg}, 1.38 \times 10^{-5} \% \mathrm{w} / \mathrm{w}\right), 3\left(t_{\mathrm{R}}=16.0 \mathrm{~min}, 2.24 \mathrm{mg}, 3.35 \times 10^{-5} \% \mathrm{w} / \mathrm{w}\right), \mathbf{9}\left(t_{\mathrm{R}}=13.0 \mathrm{~min}, 2.39\right.$ $\left.\mathrm{mg}, 3.58 \times 10^{-5} \% \mathrm{w} / \mathrm{w}\right)$, and $10\left(t_{\mathrm{R}}=11.8 \mathrm{~min}, 1.44 \mathrm{mg}, 2.16 \times 10^{-5} \% \mathrm{w} / \mathrm{w}\right)$.

\section{5,6-Dibromo-N-chloromethyl-N,N-dimethyltryptammonium (1)}

Yellow amorphous solid; UV (MeOH) $\lambda_{\max } 230,295 \mathrm{~nm} ;{ }^{1} \mathrm{H}$ NMR and ${ }^{13} \mathrm{C}$ NMR data, Tables 1 and 2; ESI(+)-HRMS m/z 392.9366 [M] (calcd. for $\mathrm{C}_{13} \mathrm{H}_{16} \mathrm{Br}_{2} \mathrm{ClN}_{2}, 392.9363, \Delta+0.8 \mathrm{ppm}$ ).

\section{5,6-Dibromo-N,N-dimethyltryptamine-N-oxide (2)}

Colorless amorphous solid; UV (MeOH) $\lambda_{\max } 230,295 \mathrm{~nm} ;{ }^{1} \mathrm{H}$ NMR and ${ }^{13} \mathrm{C}$ NMR data, Tables 1 and 2; (+)-HRESIMS m/z $360.9557[\mathrm{M}+\mathrm{H}]^{+}$(calcd. for $\mathrm{C}_{12} \mathrm{H}_{15} \mathrm{Br}_{2} \mathrm{~N}_{2} \mathrm{O}, 360.9546, \Delta+3.0 \mathrm{ppm}$ ).

\section{6,7-Dibromo-2-methyltetrahydro- $\beta$-carboline (3)}

Colorless amorphous solid; UV (MeOH) $\lambda_{\max } 231,290 \mathrm{~nm} ;{ }^{1} \mathrm{H}$ NMR and ${ }^{13} \mathrm{C}$ NMR data, Tables 1 and 2; (+)-HRESIM S m/z $342.9433[\mathrm{M}+\mathrm{H}]^{+}$(calcd. for $\mathrm{C}_{12} \mathrm{H}_{13} \mathrm{Br}_{2} \mathrm{~N}_{2}, 342.9440, \Delta-2.0 \mathrm{ppm}$ ).

\section{Narrabeenamine A (4)}

Yellow amorphous solid; $[\alpha]_{\mathrm{D}}^{20}+12(c 0.1, \mathrm{MeOH}) ; \mathrm{UV}\left(\mathrm{CH}_{3} \mathrm{CN}\right) \lambda \max (\log \varepsilon) 218$ (3.66), 260 (3.23), $310(2.83) \mathrm{nm} ; \mathrm{ECD}\left(c 2.7 \times 10^{-4} \mathrm{M}, \mathrm{CH}_{3} \mathrm{CN}\right) \lambda_{\max }(\Delta \varepsilon) 220(+0.34), 246(-0.32), 274(+0.1) \mathrm{nm} ;{ }^{1} \mathrm{H} \mathrm{NMR}$ 
and ${ }^{13} \mathrm{C}$ NMR data, Tables 1 and 2; (+)-HRESIMS $m / z 376.9503[\mathrm{M}+\mathrm{H}]^{+}$(calcd. for $\mathrm{C}_{12} \mathrm{H}_{15} \mathrm{Br}_{2} \mathrm{~N}_{2} \mathrm{O}_{2}$, $376.9495, \Delta+2.1 \mathrm{ppm})$.

Narrabeenamine B (5)

Yellow amorphous solid; $[\alpha]_{\mathrm{D}}{ }^{20}+20(c 0.1, \mathrm{MeOH}) ; \mathrm{UV}\left(\mathrm{CH}_{3} \mathrm{CN}\right) \lambda_{\max }(\log \varepsilon) 246(3.52), 310(2.96)$ $\mathrm{nm} ; \mathrm{ECD}\left(c 5.5 \times 10^{-4} \mathrm{M}, \mathrm{CH}_{3} \mathrm{CN}\right) \lambda_{\max }(\Delta \varepsilon) 245(-0.12), 270(-0.01), 310(-0.05) \mathrm{nm} ;{ }^{1} \mathrm{H}$ NMR and ${ }^{13} \mathrm{C}$ NMR data, Tables 1 and 2; (+)-HRESIMS $m / z 360.9551$ [M] ${ }^{+}$(calcd. for $\mathrm{C}_{12} \mathrm{H}_{15} \mathrm{Br}_{2} \mathrm{~N}_{2} \mathrm{O}, 360.9546, \Delta$ +1.1 ppm).

\section{5,6-Dibromokynuramine (6)}

Yellow amorphous solid; UV (MeOH) $\lambda_{\max } 235,264,376 \mathrm{~nm} ;{ }^{1} \mathrm{H}$ NMR and ${ }^{13} \mathrm{C}$ NMR data, Tables 1 and 2; (+)-HRESIMS m/z $320.9239[\mathrm{M}+\mathrm{H}]^{+}$(calcd. for $\mathrm{C}_{9} \mathrm{H}_{11} \mathrm{Br}_{2} \mathrm{~N}_{2} \mathrm{O}, 320.9233 \Delta+1.9 \mathrm{ppm}$ ).

\section{5,6-Dibromo-7-methoxykynuramine (7)}

Yellow amorphous solid; UV (MeOH) $\lambda_{\max } 240,265,377 \mathrm{~nm} ;{ }^{1} \mathrm{H}$ NMR and ${ }^{13} \mathrm{C}$ NMR data, Tables 1 and 2; (+)-HRESIMS m/z $350.9344[\mathrm{M}+\mathrm{H}]^{+}$(calcd. for $\mathrm{C}_{10} \mathrm{H}_{13} \mathrm{Br}_{2} \mathrm{~N}_{2} \mathrm{O}_{2}, 350.9338, \Delta+1.7 \mathrm{ppm}$ ).

\section{3,5-Dibromo-4-methoxy-N-methyltyramine (8)}

Colorless amorphous solid; UV (MeOH) $\lambda_{\max } 208,280 \mathrm{~nm} ;{ }^{1} \mathrm{H}$ NMR $\left(500 \mathrm{MHz}, \mathrm{CD}_{3} \mathrm{OD}\right) \delta_{\mathrm{H}} 7.55$ (s, H-2 and H-6), 3.85 (s, H-11), $3.24(\mathrm{t}, J=7.5 \mathrm{~Hz}, \mathrm{H}-8), 2.93$ (t, $J=7.5 \mathrm{~Hz}, \mathrm{H}-7), 2.72$ (s, H-10); ${ }^{13} \mathrm{C}$ NMR; (125 MHz, CD 3 OD) $\delta_{\mathrm{C}} 154.7$ (C, C-4)), 136.7 (C-1), 134.3 (C-2, C-6), 119.8 (C-3, C-5), 61.1 (C-11), 50.8 (C-8), 33.7 (C-10), 31.8 (C-7); (+)-HRESIMS m/z 321.9447 [M + H] ${ }^{+}$(calcd. for $\mathrm{C}_{10} \mathrm{H}_{14} \mathrm{Br}_{2} \mathrm{NO}, 321.9437$, $\Delta+3.1 \mathrm{ppm})$.

\subsection{Computational Methods}

ECD. The low energy conformers of each compound were generated using the Schrodinger MacroModel 11.3 software package in Maestro release 2017-4 (Schrödinger, LLC, New York, NY, USA) as described previously [53]. The conformers were optimized using Gaussian 16 (Wallingford, CT, USA) at the B3LYP/6-311+G(d,p) level of theory, while at the same time, the zero-point energy, electronic transition, and rational strength of conformers were calculated for the free-energy distribution of the conformers [54]. The ECD spectrum was calculated using Gaussian 16 at the B3LYP/6-31G(d) level, and spectra were produced using the freely available software SpecDis 1.7 (Berlin, Germany) [55]. All calculations were performed using a polarizable continuum model with acetonitrile. The calculated spectra were then compared to the experimental spectra.

MetWork v0.3.5, Paris, France. Raw MS/MS data were converted into .mgf using MSconvert v3.0.18105-622e002cb, and a molecular network was created using the online workflow at GNPS [51]. The data were filtered by removing all MS/MS peaks within $+/-17$ Da of the precursor $m / z$. MS/MS spectra were window filtered by choosing only the top 6 peaks in the $+/-50 \mathrm{Da}$ window throughout the spectrum. A network was then created where edges were filtered to have a cosine score above 0.7 and more than 3 matched peaks. Further edges between two nodes were kept in the network if and only if each of the nodes appeared in each other's respective top 10 most similar nodes. The corresponding clustered .mgf was then uploaded to the MetWork server [49]. Compound $\mathbf{1 3}$ was used for the in silico metabolization using indole-related biotransformations. For the comparison between experimental and predicted MS/MS spectra, a cosine value threshold of 0.45 was used. 


\subsection{Bioassays}

\section{Cell Culture}

Murine microglia BV-2 cell line was purchased from InterLab Cell Line Collection (ICLC, Genoa, Italy), number ATL03001. Cells were maintained in Roswell Park Memorial Institute Medium (RPMI), plus $10 \%$ fetal bovine serum (FBS), $100 \mu \mathrm{g} / \mathrm{mL}$ streptomycin and penicillin $(100 \mathrm{U} / \mathrm{mL})$ at $37^{\circ} \mathrm{C}$ in a humidified atmosphere of $5 \% \mathrm{CO}_{2}$ and $95 \%$ air. Cells were dissociated twice a week using $0.05 \%$ trypsin/ethylenediaminetetracetic acid (EDTA).

Human neuroblastoma SH-SY5Y cell line was obtained from American Type Culture Collection (ATCC), number CRL2266. Cells were maintained in Dulbecco's Modified Eagle Medium: Nutrient Mix F-12 (DMEN/F-12) plus 10\% FBS, 1\% glutamax, $100 \mu \mathrm{g} / \mathrm{mL}$ streptomycin and penicillin $(100 \mathrm{U} / \mathrm{mL})$ at $37^{\circ} \mathrm{C}$ in a humidified atmosphere of $5 \% \mathrm{CO}_{2}$ and $95 \%$ air. Cells were dissociated once a week using $0.05 \%$ trypsin/EDTA.

\section{Cell Viability}

The MTT assay was used to analyze cell viability. Briefly, microglia BV2 cells were cultured in 384 well plates at a density of $2 \times 10^{4}$ cells per well or $2.5 \times 10^{4}$ cells per well in the case of neuroblastoma SH-SY5Y cells. Cells were incubated with different compound concentrations $(0.001$, $0.01,0.1,1$, and $10 \mu \mathrm{M})$ for $24 \mathrm{~h}$. Then, cells were washed and incubated with MTT [3-(4,5-dimethyl thiazol-2-yl)-2,5-diphenyl tetrazolium bromide] (500 $\mu \mathrm{g} / \mathrm{mL}$ ) diluted in phosphate buffered saline (PBS) for $1 \mathrm{~h}$ at $37^{\circ} \mathrm{C}$. The resulting formazan crystals were dissolved with sodium dodecyl sulfate (SDS), and the absorbance was measured on a spectrophotometer plate reader at $595 \mathrm{~nm}$ (Bio-Tek Synergy, Winooski, VT, USA).

\section{Neuroprotection Assay}

The neuroprotective effects on cellular viability of compounds in the presence of TBHP were measured by the MTT assay as described above. For this, cells were incubated with compounds at different concentrations $(0.001,0.01,0.1,1$, and $10 \mu \mathrm{M})$ and TBHP $(65 \mu \mathrm{M})$ for $6 \mathrm{~h}$. The known antioxidant vitamin $\mathrm{E}(25 \mu \mathrm{M})$ was used as a positive control for neuroprotective activity.

\section{NO Determination}

The NO concentration in the culture medium was determined using the Griess reagent kit (Thermo Fisher, Madrid, Spain), in accordance with manufacturer's instructions. Briefly, microglia BV2 cells were seeded in 24 -well plates $\left(1 \times 10^{6}\right.$ cells per well) and incubated with compounds $(1$ and $0.1 \mu \mathrm{M})$ $1 \mathrm{~h}$ before the stimulation with LPS $(500 \mathrm{ng} / \mathrm{mL})$ for $24 \mathrm{~h}$. Next, in a 96-well plate it was added 130 $\mu \mathrm{L}$ of deionized water, $150 \mu \mathrm{L}$ of cells in culture medium, and $20 \mu \mathrm{L}$ of Griess reagent and then it was incubated for $30 \mathrm{~min}$ in the dark and at room temperature. The absorbance was measured on a spectrophotometer plate reader at $548 \mathrm{~nm}$ (Bio-Tek Synergy).

\section{Conclusions}

This work represents the first chemical study of a sponge from the genus Narrabeena. The chemical investigation of the Pacific sponge Narrabeena nigra collected around the Futuna Islands led to the isolation of a large diversity of simple bromotryptamine and bromotyramine derivatives. As analogues of these families were also found in other marine invertebrates, we hypothesize a microbial origin for these compounds. The use of the webserver MetWork allowed the identification of minor possible biosynthetic intermediates through natural product anticipation based on comparison with calculated MS/MS data.

Overproduction of reactive oxygen species (ROS) generates an oxidative stress state which is related to neurodegenerative diseases. Oxidative stress occurs upon an excessive ROS production 
and deficiency of an antioxidant response [56]. Therefore, compounds able to protect neurons against oxidative damage are excellent candidates to be used in neurodegenerative disorders, such as Alzheimer's or Parkinson's disease [57]. In the present work, human neuroblastoma SH-SY5Y cells treated with TBHP for 6 hours were consolidated as a model of oxidative stress damage. Some of the brominated alkaloids, like 5 , showed an interesting neuroprotective effect against TBHP-induced oxidative damage in SH-SY5Y cells, in the same way as the potent antioxidant vitamin E. In addition, seven of these compounds decreased the release of the neurotoxic mediator NO in activated microglia. Activated microglia play a crucial role in neuroinflammation through the excessive production of pro-inflammatory mediators. Further, microglia-mediated inflammation has been related to neurodegenerative diseases [58]. Moreover, these brominated alkaloids showed very low toxicity, up to $10 \mu \mathrm{M}$, in neuron and microglia cell lines. All these results suggest the potential of these natural products as a therapeutic tool to prevent neuronal cell death in age-associated diseases. A recent publication confirms the potential of some oxidized analogues in this series [59]. Nevertheless, further studies will be necessary to better understand the mechanism of action of these compounds.

Supplementary Materials: All NMR, ECD and MS spectra are available online at http://www.mdpi.com/16603397/17/6/319/s1.

Author Contributions: Conceptualization, A.A., O.P.T., S.G. and M.M.-G.; methodology, J.V., S.G., M.M.-G., A.A. and K.C.; software, G.G.-J. and L.K.J.; validation, J.V., K.C. and A.A.; writing-original draft preparation, M.M.-G.; writing-review and editing, O.P.T. and L.M.B.; supervision, K.C. and A.A.; project administration, O.P.T.; funding acquisition, O.P.T. and L.M.B.

Funding: We are keen to thank the commitment of the people and the following institutions for their financial and scientific support that made this singular expedition possible: CNRS, PSL, CSM, EPHE, Genoscope/CEA, Inserm, Université Cote d'Azur, ANR, agnès b., UNESCO-IOC, the Veolia Environment Foundation, Région Bretagne, Serge Ferrari, Billerudkorsnas, Amerisource Bergen Company, Lorient Agglomeration, Oceans by Disney, the Prince Albert II de Monaco Foundation, L'Oréal, Biotherm, France Collectivités, Kankyo Station, Fonds Français pour l'Environnement Mondial (FFEM), Etienne BOURGOIS, the Tara Foundation teams and crew. Tara Pacific would not exist without the continuous support of the participating institutes. Part of this project (Grant-Aid Agreement No. PBA/MB/16/01) is carried out with the support of the Marine Institute and is funded under the Marine Research Program by the Irish Government. M.M.G. acknowledges James Hardiman Research Scholarship (NUI Galway) for supporting her Ph.D. The research leading to the results on bioassays has received funding from the following FEDER co-funded grants: Consellería de Cultura, Educación e Ordenación Universitaria Xunta de Galicia, 2017 GRC GI-1682 (ED431C 2017/01); CDTI and Technological Funds, supported by Ministerio de Economía, Industria y Competitividad, AGL2014-58210-R, AGL2016-78728-R (AEI/FEDER, UE), ISCIII/PI16/01830 and RTC-2016-5507-2, ITC-20161072. From European Union POCTEP 0161-Nanoeaters-1-E-1, Interreg AlertoxNet EAPA-317-2016, Interreg Agritox EAPA-998-2018 and H2020 778069- EMERTOX. S.G. was supported by a fellowship from FIDIS, Spain.

Acknowledgments: We are deeply grateful to The Tara Foundation teams and crew members for their support during the field trip to Futuna. Support and permission to undertake this study were provided by Atoloto Malau (Service de l'environnement, Wallis and Futuna). Roisin Doohan (NUIG) is acknowledged for recording some NMR experiments. We acknowledge the Irish center for high-end computing (ICHEC) for their support and access to the computational resources for DFT calculations.

Conflicts of Interest: The authors declare no conflict of interest. The funders had no role in the design of the study; in the collection, analyses, or interpretation of data; in the writing of the manuscript, or in the decision to publish the results.

\section{References}

1. Firsova, D.; Mahajan, N.; Solanki, H.; Morrow, C.; Thomas, O.P. Current Status and Perspectives in Marine Biodiscovery. In Bioprospecting: Success, Potential and Constraints; Paterson, R., Lima, N., Eds.; Springer International Publishing AG: Cham, Switzerland, 2017; Volume 16, pp. $29-50$.

2. Jaspars, M.; De Pascale, D.; Andersen, J.H.; Reyes, F; Crawford, A.D.; Ianora, A. The marine biodiscovery pipeline and ocean medicines of tomorrow. J. Mar. Biol. Assoc. UK 2016, 96, 151-158. [CrossRef]

3. Snelgrove, P.V.R. An Ocean of Discovery: Biodiversity Beyond the Census of Marine Life. Planta Med. 2016, 82, 790-799. [CrossRef]

4. Blunt, J.W.; Carroll, A.R.; Copp, B.R.; Davis, R.A.; Keyzers, R.A.; Prinsep, M.R. Marine natural products. Nat. Prod. Rep. 2018, 35, 8-53. [CrossRef] [PubMed] 
5. Bowen, B.W.; Rocha, L.A.; Toonen, R.J.; Karl, S.A. The origins of tropical marine biodiversity. Trends Ecol. Evol. 2013, 28, 359-366. [CrossRef] [PubMed]

6. Tara-Expeditions-Foundation Annual report 2017. Available online: https://oceans.taraexpeditions.org/en/ (accessed on 25 April 2019).

7. Chancerelle, Y. Coral reefs of Wallis and Futuna: Biological monitoring, health and future. Rev. Ecol.-Terre Vie 2008, 63, 133-143.

8. Pichon, M. Scleractinia of New Caledonia: Check list of reef dwelling species. In Compendium of Marine Species from New-Caledonia, 2nd ed.; Payri, C.E., Richer de Forges, B., Eds.; IRD: Noumea, New-Caledonia, France, 2007; pp. 149-157.

9. Eléonore Vandel, M.P. Pascale Joannot. In Taxonomic Inventory of Scleractinia in French Overseas Territories, Proceedings of the 12th International Coral Reef Symposium, Cairns, Australia, 9-13 June 2012; James Cook University: Townsville, Australia.

10. Kim, H.R.; Sim, C.J. A New Species of the Genus Narrabeena (Demospongiae: Dictyoceratida: Thorectidae) from Korea. Korean J. Syst. Zool. 2010, 26, 83-86. [CrossRef]

11. Prawat, H.; Mahidol, C.; Kaweetripob, W.; Wittayalai, S.; Ruchirawat, S. Iodo-sesquiterpene hydroquinone and brominated indole alkaloids from the Thai sponge Smenospongia sp. Tetrahedron 2012, 68, 6881-6886. [CrossRef]

12. Tasdemir, D.; Bugni Timothy, S.; Mangalindan Gina, C.; Concepción Gisela, P.; Harper Mary, K.; Ireland Chris, M. Cytotoxic Bromoindole Derivatives and Terpenes from the Philippine Marine Sponge Smenospongia sp. Z. Naturforsch. C Biosci. 2002, 57, 914. [CrossRef]

13. Schoenfeld, R.C.; Conova, S.; Rittschof, D.; Ganem, B. Cytotoxic, antifouling bromotyramines: A synthetic study on simple marine natural products and Their analogues. Bioorg. Med. Chem. Lett. 2002, 12, 823-825. [CrossRef]

14. Longeon, A.; Copp, B.R.; Quevrain, E.; Roue, M.; Kientz, B.; Cresteil, T.; Petek, S.; Debitus, C.; Bourguet-Kondracki, M.L. Bioactive Indole Derivatives from the South Pacific Marine Sponges Rhopaloeides odorabile and Hyrtios sp. Mar. Drugs 2011, 9, 879-888. [CrossRef]

15. Kochanowska, A.J.; Rao, K.V.; Childress, S.; El-Alfy, A.; Matsumoto, R.R.; Kelly, M.; Stewart, G.S.; Sufka, K.J.; Hamann, M.T. Secondary Metabolites from Three Florida Sponges with Antidepressant Activity. J. Nat. Prod. 2008, 71, 186-189. [CrossRef] [PubMed]

16. Djura, P.; Stierle, D.B.; Sullivan, B.; Faulkner, D.J. Some Metabolites of the Marine Sponges Smenospongia aurea and Smenospongia (Polyfibrospongia) echina. J. Org. Chem. 1980, 45, 1435-1441. [CrossRef]

17. Tymiak, A.A.; Rinehart, K.L.; Bakus, G.J. Constituents of morphologically similar sponges: Aplysina and Smenospongia species. Tetrahedron 1985, 41, 1039-1047. [CrossRef]

18. Van Lear, G.E.; Morton, G.O.; Fulmor, W. New antibacterial bromoindole metabolites from the marine sponge Polyfibrospongia maynardii. Tetrahedron Lett. 1973, 14, 299-300. [CrossRef]

19. Pénez, N.; Culioli, G.; Pérez, T.; Briand, J.-F.; Thomas, O.P.; Blache, Y. Antifouling Properties of Simple Indole and Purine Alkaloids from the Mediterranean Gorgonian Paramuricea clavata. J. Nat. Prod. 2011, 74, 2304-2308. [CrossRef]

20. Fahy, E.; Potts, B.C.M.; Faulkner, D.J.; Smith, K. 6-Bromotryptamine Derivatives from the Gulf of California Tunicate Didemnum candidum. J. Nat. Prod. 1991, 54, 564-569. [CrossRef]

21. Olsen, E.K.; Hansen, E.; L, W.K.M.; Isaksson, J.; Sepcic, K.; Cergolj, M.; Svenson, J.; Andersen, J.H. Marine AChE inhibitors isolated from Geodia barretti: natural compounds and their synthetic analogs. Org. Biomol. Chem. 2016, 14, 1629-1640. [CrossRef] [PubMed]

22. Al Tarabeen, M.; Hassan Aly, A.; Perez Hemphill Catalina, F.; Rasheed, M.; Wray, V.; Proksch, P. New nitrogenous compounds from a Red Sea sponge from the Gulf of Aqaba. Z. Naturforsch. C Biosci. 2015, 70, 75. [CrossRef] [PubMed]

23. Van Wagoner, R.M.; Jompa, J.; Tahir, A.; Ireland, C.M. Trypargine Alkaloids from a Previously Undescribed Eudistoma sp. Ascidian. J. Nat. Prod. 1999, 62, 794-797. [CrossRef] [PubMed]

24. Albrizio, S.; Ciminiello, P.; Fattorusso, E.; Magno, S.; Pansini, M. Chemistry of Verongida sponges. I. Constituents of the Caribbean sponge Pseudoceratina crassa. Tetrahedron 1994, 50, 783-788. [CrossRef]

25. Afoullouss, S.; Calabro, K.; Genta-Jouve, G.; Gegunde, S.; Alfonso, A.; Nesbitt, R.; Morrow, C.; Alonso, E.; Botana, L.M.; Allcock, A.L.; Thomas, O.P. Treasures from the Deep: Characellides as Anti-Inflammatory Lipoglycotripeptides from the Sponge Characella pachastrelloides. Org. Lett. 2019, 21, 246-251. [CrossRef] 
26. Buchanan, M.S.; Carroll, A.R.; Pass, D.; Quinn, R.J. NMR spectral assignments of a new chlorotryptamine alkaloid and its analogues from Acacia confusa. Magn. Reson. Chem. 2007, 45, 359-361. [CrossRef]

27. Capon, R.J. Extracting value: mechanistic insights into the formation of natural product artifacts - case studies in marine natural products. Nat. Prod. Rep. 2019. [CrossRef]

28. El-Shazly, A.; Wink, M. Tetrahydroisoquinoline and beta-carboline alkaloids from Haloxylon articulatum (Cav.) Bunge (Chenopodiaceae). Z. Naturforsch. C Biosci. 2003, 58, 477-480. [CrossRef]

29. Cheng, G.-G.; Li, D.; Hou, B.; Li, X.-N.; Liu, L.; Chen, Y.-Y.; Lunga, P.-K.; Khan, A.; Liu, Y.-P.; Zuo, Z.-L.; et al. Melokhanines A-J, Bioactive Monoterpenoid Indole Alkaloids with Diverse Skeletons from Melodinus khasianus. J. Nat. Prod. 2016, 79, 2158-2166. [CrossRef]

30. Ruiz-Sanchis, P.; Savina, S.A.; Albericio, F.; Álvarez, M. Structure, Bioactivity and Synthesis of Natural Products with Hexahydropyrrolo[2,3-b]indole. Chem. A Eur. J. 2011, 17, 1388-1408. [CrossRef]

31. Yan, A.; Liu, Z.; Song, L.; Wang, X.; Zhang, Y.; Wu, N.; Lin, J.; Liu, Y. Idebenone Alleviates Neuroinflammation and Modulates Microglial Polarization in LPS-Stimulated BV2 Cells and MPTP-Induced Parkinson's Disease Mice. Front. Cell. Neurosci. 2018, 12, 529. [CrossRef]

32. Markoutsa, E.; Xu, P. Redox Potential-Sensitive N-Acetyl Cysteine-Prodrug Nanoparticles Inhibit the Activation of Microglia and Improve Neuronal Survival. Mol Pharm 2017, 14, 1591-1600. [CrossRef]

33. Colton, C.A. Heterogeneity of microglial activation in the innate immune response in the brain. J. Neuroimmune Pharmacol. 2009, 4, 399-418. [CrossRef]

34. Cravotto, G.; Giovenzana, G.B.; Palmisano, G.; Penoni, A.; Pilati, T.; Sisti, M.; Stazi, F. Convolutamydine A: the first authenticated absolute configuration and enantioselective synthesis. Tetrahedron: Asymmetry 2006, 17, 3070-3074. [CrossRef]

35. Zhang, H.-P.; Kamano, Y.; Ichihara, Y.; Kizu, H.; Komiyama, K.; Itokawa, H.; Pettit, G.R. Isolation and structure of convolutamydines B D from marine bryozoan Amathia convoluta. Tetrahedron 1995, 51, 5523-5528. [CrossRef]

36. Carle, J.S.; Christophersen, C. Bromo-substituted physostigmine alkaloids from a marine bryozoa Flustra foliacea. J. Am. Chem. Soc. 1979, 101, 4012-4013. [CrossRef]

37. Carle, J.S.; Christophersen, C. Marine alkaloids. 2. Bromo alkaloids from a marine bryozoan Flustra foliacea. Isolation and structure elucidation. J. Org. Chem. 1980, 45, 1586-1589. [CrossRef]

38. Carle, J.S.; Christophersen, C. Marine alkaloids. 3. Bromo-substituted alkaloids from the marine bryozoan Flustra foliacea, flustramine C and flustraminol A and B. J. Org. Chem. 1981, 46, 3440-3443. [CrossRef]

39. Blackman, A.J.; Matthews, D.J.; Narkowicz, C.K. $\beta$-Carboline alkaloids from the marine bryozoan Costaticella hastata. J. Nat. Prod. 1987, 50, 494-496. [CrossRef]

40. Salmoun, M.; Devijver, C.; Daloze, D.; Braekman, J.-C.; van Soest, R.W.M. 5-Hydroxytryptamine-Derived Alkaloids from Two Marine Sponges of the Genus Hyrtios. J. Nat. Prod. 2002, 65, 1173-1176. [CrossRef]

41. Mokhlesi, A.; Stuhldreier, F.; Wex, K.W.; Berscheid, A.; Hartmann, R.; Rehberg, N.; Sureechatchaiyan, P.; Chaidir, C.; Kassack, M.U.; Kalscheuer, R.; et al. Cyclic Cystine-Bridged Peptides from the Marine Sponge Clathria basilana Induce Apoptosis in Tumor Cells and Depolarize the Bacterial Cytoplasmic Membrane. J. Nat. Prod. 2017, 80, 2941-2952. [CrossRef]

42. Tian, X.-R.; Tang, H.-F.; Li, Y.-S.; Lin, H.-W.; Zhang, X.-Y.; Feng, J.-T.; Zhang, X. Studies on the chemical constituents from marine bryozoan Cryptosula pallasiana. Rec. Nat. Prod. 2015, 9, 628-632.

43. Brogan, J.T.; Stoops, S.L.; Crews, B.C.; Marnett, L.J.; Lindsley, C.W. Total Synthesis of (+)-7-Bromotrypargine and Unnatural Analogues: Biological Evaluation Uncovers Activity at CNS Targets of Therapeutic Relevance. ACS Chem. Neurosci. 2011, 2, 633-639. [CrossRef]

44. Wang, D.; Feng, Y.; Murtaza, M.; Wood, S.; Mellick, G.; Hooper, J.N.A.; Quinn, R.J. A Grand Challenge: Unbiased Phenotypic Function of Metabolites from Jaspis splendens against Parkinson's Disease. J. Nat. Prod. 2016, 79, 353-361. [CrossRef]

45. Aoki, S.; Ye, Y.; Higuchi, K.; Takashima, A.; Tanaka, Y.; Kitagawa, I.; Kobayashi, M. Novel neuronal nitric oxide synthase (nNOS) selective inhibitors, aplysinopsin-type indole alkaloids, from marine sponge Hyrtios erecta. Chem. Pharm. Bull. 2001, 49, 1372-1374. [CrossRef]

46. Pimentel, S.M.V.; Bojo, Z.P.; Roberto, A.V.D.; Lazaro, J.E.H.; Mangalindan, G.C.; Florentino, L.M.; Lim-Navarro, P.; Tasdemir, D.; Ireland, C.M.; Concepcion, G.P. Platelet Aggregation Inhibitors from Philippine Marine Invertebrate Samples Screened in a New Microplate Assay. Mar. Biotechnol. 2003, 5, 395-400. [CrossRef] 
47. Ciminiello, P.; Dell'Aversano, C.; Fattorusso, E.; Magno, S.; Pansini, M. Chemistry of Verongida sponges. 10. Secondary metabolite composition of the Caribbean sponge Verongula gigantea. J. Nat. Prod. 2000, 63, 263-266. [CrossRef]

48. Tian, L.-W.; Feng, Y.; Shimizu, Y.; Pfeifer, T.; Wellington, C.; Hooper, J.N.A.; Quinn, R.J. Aplysinellamides A-C, Bromotyrosine-Derived Metabolites from an Australian Aplysinella sp. Marine Sponge. J. Nat. Prod. 2014, 77, 1210-1214. [CrossRef]

49. Beauxis, Y.; Genta-Jouve, G. MetWork: A web server for natural products anticipation. Bioinformatics 2018, 35, 1795-1796. [CrossRef]

50. Moore, B.S.; Luhavaya, H.; Sigrist, R.; Chekan, J.R.; McKinnie, S.M.K. Biosynthesis of L-4-Chlorokynurenine, a Lipopeptide Antibiotic Non-Proteinogenic Amino Acid and Antidepressant Prodrug. Angew. Chem. Int. Ed. 2019, 58, 1-7.

51. Wang, M.; Carver, J.J.; Phelan, V.V.; Sanchez, L.M.; Garg, N.; Peng, Y.; Nguyen, D.D.; Watrous, J.; Kapono, C.A.; Luzzatto-Knaan, T.; et al. Sharing and community curation of mass spectrometry data with Global Natural Products Social Molecular Networking. Nat. Biotechnol. 2016, 34, 828. [CrossRef]

52. Audoin, C.; Cocandeau, V.; Thomas, P.O.; Bruschini, A.; Holderith, S.; Genta-Jouve, G. Metabolome Consistency: Additional Parazoanthines from the Mediterranean Zoanthid Parazoanthus Axinellae. Metabolites 2014, 4, 421-432. [CrossRef]

53. Willoughby, P.H.; Jansma, M.J.; Hoye, T.R. A guide to small-molecule structure assignment through computation of (1H and 13C) NMR chemical shifts. Nat. Prot. 2014, 9, 643. [CrossRef]

54. Tomasi, J.; Mennucci, B.; Cammi, R. Quantum Mechanical Continuum Solvation Models. Chem. Rev. 2005, 105, 2999-3094. [CrossRef]

55. Bruhn, T.; Schaumlöffel, A.; Hemberger, Y.; Bringmann, G. SpecDis: Quantifying the Comparison of Calculated and Experimental Electronic Circular Dichroism Spectra. Chirality 2013, 25, 243-249. [CrossRef]

56. Bhattacharya, S.; Gachhui, R.; Sil, P.C. Hepatoprotective properties of kombucha tea against TBHP-induced oxidative stress via suppression of mitochondria dependent apoptosis. Pathophysiology 2011, 18, 221-234. [CrossRef]

57. Leirós, M.; Sánchez, J.A.; Alonso, E.; Rateb, M.E.; Houssen, W.E.; Ebel, R.; Jaspars, M.; Alfonso, A.; Botana, L.M. Spongionella secondary metabolites protect mitochondrial function in cortical neurons against oxidative stress. Mar. Drugs 2014, 12, 700-718. [CrossRef]

58. González-Scarano, F.; Baltuch, G. Microglia as mediators of inflammatory and degenerative diseases. Annu. Rev. Neurosci. 1999, 22, 219-240. [CrossRef]

59. Stanley, C.P.; Maghzal, G.J.; Ayer, A.; Talib, J.; Giltrap, A.M.; Shengule, S.; Wolhuter, K.; Wang, Y.; Chadha, P.; Suarna, C.; et al. Singlet molecular oxygen regulates vascular tone and blood pressure in inflammation. Nature 2019, 566, 548-552. [CrossRef]

(C) 2019 by the authors. Licensee MDPI, Basel, Switzerland. This article is an open access article distributed under the terms and conditions of the Creative Commons Attribution (CC BY) license (http://creativecommons.org/licenses/by/4.0/). 